\title{
Yabancılaşma ve Özsaygı: Çoğulcu Eleştiriler Üzerinden Bir Değerlendirme
}

\begin{abstract}
Alihan GÖK*
Nial TEKİN ${ }^{* *}$

Öz

Çağdaş siyaset felsefesi yazınında Marksist yabancılaşma kavramına pek az yer verilir. Bunun nedeni yabancılaşma kavramının barındırdığına inanılan tekil iyi yaşam anlayışının demokrasi kültürünün vazgeçilmez bir ilkesi olan değer çoğulculuğuna aykırı olduğunun düşünülmesidir. Bu yaygın görüşün aksine, yabancılaşma kavramından yola çıkılarak yabancılaşmanın olmadığı yerde tek bir iyi yaşam biçiminin var olabileceği sonucuna varılamaz. Günümüz kapitalist toplumlarında sürekli liberal çoğulcu değerlerin vaaz edilmesine rağmen sistematik olarak tek boyutlu bir tüketim hayatının dayatılmasının getirdiği alternatifsizlik, yabancılaşma ve bu kavrama yöneltilen çoğulcu itirazlar üzerine yeniden düşünmemiz gerektiğini göstermektedir. John Rawls'un adalet kuramında (A Theory of Justice) en önemli toplumsal kaynak olarak, Marksist yabancılaşma kavramının içerdiği "kendini gerçekleştirme" düşüncesiyle paralellikler taşıyan "özsaygı" kavramına yer vermesi bu bakımdan anlamlıdır. Ancak Marksist yabancılaşma kuramının eleştirel ve dönüştürücü yapısı göz önünde bulundurulduğunda yabancılaşma kavramıla bazı benzerlikler taşıyan özsaygı kavramının yetersizliklerinin de ortaya konması gerekmektedir.
\end{abstract}

Anahtar kelimeler: Yabancılaşma, özsaygı, çoğulculuk, kendini gerçekleştirme.

\section{Alienation and Self-Respect: An Evaluation Through Pluralistic Critiques}

\begin{abstract}
In contemporary political philosophy, the Marxist concept of alienation takes few places. The reason behind this is the belief that the concept of alienation includes a unique good life perception which

* Araştırma Görevlisi, Marmara Üniversitesi, Siyasal Bilgiler Fakültesi, Kamu Yönetimi (Fransızca) Bölümü. E-posta: alihan.gok@marmara.edu.tr

** Araştırma Görevlisi, Centre Pierre Naville, Université d’Évry Val-d'Essone. E-posta: tekinnial@gmail.com
\end{abstract}


contradicts with the value pluralism that is considered as an indispensable principle of democratic culture. In opposite to that widespread idea, from the point of concept of alienation it couldn't be concluded that a unique goof lifestyle could exist in the absence of alienation. Despite the fact that today's capitalist societies' liberal pluralistic values have constantly been preaching, the alternativeness arising from the imposition of one dimensional consumption based life that shows us the necessity to rethink the concept of alienation and also many rejections made against it. In this regard, it is meaningful that John Rawls allocates a place to the concept of "self-respect", which has many similarities with the idea of "self-realization" that the Marxist concept of alienation includes, as an important social resource in A Theory of Justice. Nevertheless, by taking into account the critical and transformative structure of Marxist alienation theory, the insufficiencies of the concept of self-respect must also be revealed.

Keywords: Alienation, self-respect, pluralism, self-realization.

\section{Giriş}

Toplumsal adalet ve çoğulculuk sorunları, çağdaş liberal siyasi düşüncenin ana temalarındandır. $\mathrm{Bu}$ temaların kesiştiği yerde, toplumsal kaynakların ve yükümlülüklerin dağılımdan sorumlu mekanizmaların farklı iyi yaşam anlayışlarına ve yaşam projelerine karşı eşit mesafede durması gerektiği fikri yatar. Böylece "adil” olanla "iyi” olanın, demokrasi kültürüne aşina bir toplum için birbirine engel olmayacak biçimde tanımlanabileceği düşünülür.

Çağdaş siyaset felsefesine damgasını vurmuş liberal eşitlikçi düşünürlerden biri olan John Rawls, toplumsal adalet adına toplumsal kaynakların hakkaniyetli dağılımı için gereken ilkeleri ortaya koyduğu A Theory of Justice'de (1971) böyle bir ideal toplumu resmeder. Bu ideal modelde temel toplumsal kaynakların (primary social goods) ${ }^{1}$ hakkaniyetli bir biçimde dağıtılarak, eşitsizliklerin öncelikle en kötü durumda olanların durumunu iyileştirecek şekilde düzenlenmesi gerekir. Böylesi bir düzenlemede temel hak ve özgürlükler ön plandadır ve bunlar fayda ya da başka herhangi bir toplumsal değer adına çiğnenemez. Adaletin öncelikle kurumların erdemi olduğu adil toplumlarda istikrar (stability), bireylerin adalet anlayışlarının örtüşmesine bağlıdır. Ancak çağdaş demokratik toplumların birbirinden çok farklı iyi yaşam anlayışlarına sahip olan bireylerden meydana geldiği göz önünde bulundurulduğunda, ilkelerle belirlenen bir adalet anlayışının herkes tarafından paylaşılmasını beklemek liberal çoğulculukla bağdaşmayabilir.

Rawls, çalışmalarının ilerleyen döneminde kuramına liberallerden gelen çoğulcu itirazlara cevaben, farklı iyi yaşam anlayışlarına sahip bireylerin ortak bir adalet anlayışını paylaşabilmeleri için iyi yaşam anlayışları arasında makul olanlar ve olmayanlar şeklinde bir ayrıma gider. $\mathrm{Bu}$ kimi liberalleri tatmin etmese de geç Rawls’un çoğulculuk sorunları karşısında eskisine göre daha temkinli olduğu açıktır. Rawls, Justice as Fairness, A Restatement'de (2001) 1993'de yayımlanan Political Liberalism adlı eserinde üzerine eğildiği çoğulculuk sorununu dikkate alarak kuramını gözden geçirmiştir. Böylece akılcı olandan makul olana doğru meyleden 'iyi' anlayışı bireylerin

1 Toplumsal kaynaklar temel hak ve özgürlükler, gelir ve servet, özsaygının toplumsal temelleri gibi unsurları içerir (Rawls, 2008:58-59). 
sahip olduğu kapsayıcı doktrinlerin örtüşebileceği bir düzleme çekilerek, kuram, liberal çoğulculukla daha barışık hale getirilmiştir. Ne var ki Rawls, 'adilin iyiye üstünlügü’' (priority of the right over the good) olarak formüle ettiği özgün kuramında, toplumsal kaynaklardan biri, hatta en önemlisi olarak özsaygıdan söz eder. Aslında bir 'iyi yaşam anlayışı' barındıran bu kavram, kimilerine göre yabancılaşmadan hiç söz etmeyen Rawls’un kuramında örtük bir yabancılaşma anlayışı bulunduğunun kanıtıdır (Brudney, 2014). Tek bir iyi yaşam anlayışına dayalı olduğu için liberal değer çoğulculuğunu benimseyen yaklaşımlar yabancılaşmaya yer vermezken ${ }^{2}$ çoğulculuk sorunlarını oldukça ciddiye alan Rawls'un, kimi yazarların bu kavramla ilişkilendirdiği özsaygı kavramına geç dönem eserlerinde de yer veriyor olmasının bir nedeni olmalıdır.

Karl Marx yabancılaşma kuramını 1844 El Yazmaları: Ekonomi Politik ve Felsefe (2011) adlı eserinin merkezine koymuştur. Paris El Yazmaları olarak da bilinen bu eser, aslında ne bir kitap ne de birbirini takip eden bölümlerin oluşturduğu planlı bir metindir. El Yazmaları, Marx’ın Paris’te geçirdiği süre boyunca modern endüstrileşmenin yarattığı durumları analiz ederek yazdığı metinlerin kendisinden sonra yapılan derlemesidir. $\mathrm{Bu}$ nedenle metinler arasında tutarlılık aramak yerine, E. Renault’nun da önerdiği gibi eserin tamamını yabancılaşma konusunu anlamak üzere verilmiş bir kavramsal araçlar bütünü olarak düşünebiliriz (2006:97). Bu eserinde Marx, özel mülkiyeti kendi başına bir olgu olarak değil, yabancılaşmış emeğin bir sonucu olarak tanıtır: "Özel mülkiyet, demek ki yabancılaşmış emeğin, isçinin doğa ve kendi kendisiyle dışsal ilişkisinin ürünü değil, sonucu zorunlu vargısıdır.” (2011:72)

El Yazmalarinda yabancılaşmaya ayırdığı bölümde güncel bir iktisadi olgudan yola çıktığının altını çizen Marx, yabancılaşmış emeğin üretim eyleminde dört vargısından söz eder (2011:62) ${ }^{3}$. İlk boyut, emeğin ürünüyle olan ilişkisidir. Üretim sürecinde emek nesneleşir ve bu nesneleşme (objectivation, Vergegenständlichung), Marx’a göre olumlu bir kavramdır. Yabancılaşma, nesneleşme sürecinde değil, emek nesnesinin, emekten bağımsızlaşıp ona yabancı ve hatta egemen bir hale bürünmesiyle ortaya çıkar. Yabancılaşma etkinliğin edilgenliğe dönüşmesi, gücün güçsüzlüğe ve bu koşullarda eylemin başka, yabancı bir şeye dönüşmesidir. Özne, nesnede nesnelleşir, tüm zenginliğini nesneye verir. Başka bir deyişle nesne, özneyi yoksullaştırarak zenginleşir. "Yani ne kadar çok üretirse, sefaleti o kadar büyür" (2011:60). Bu nedenle, öznenin nesneleşmesi soyut bir nesneleşme iken nesne, somut bir zenginleşme yaşar. Üretici öznesinden bağımsızlaşan özerk nesne, özneye egemen olur. Almanca Entäusserung kavramına denk gelen bu boyutta yabancılaşma, bireyin nesneleşme sürecinde kendini ifade edemeyişidir. Bu noktada,

2 Will Kymlicka, insan doğasına ilişkin kabullerin insani yetkinliği oluşturduğu iddia edilen bazı yaşam biçimlerini, diğer yaşam biçimlerine göre daha değerli olarak gördüğü için yabancılaşma kavramının mükemmeliyetçi olduğunu savunur. Bu bakış açısına göre yabancılaşma şayet kurtulunması gereken bir durumsa bu iddianın ardında insanın aslında ne olduğu, nasıl yaşaması gerektiğine dair bazı ön kabullerin yatıyor olması gerekir. Ancak farklı iyi yaşam anlayışları ya da yaşam projeleriyle çatışmayan bir yabancılaşma kuramının tutarlı olamayacağını savunmak biraz aceleci bir çıkarım olabilir. Yabancılaşma kuramlarının kaçınılmaz olarak mükemmeliyetçi olduğu iddiası için bkz. Kymlicka (2006).

3 Dolayısıyla Marx’’n kuramlarının birbiriyle ilişkili olmaktan öte birbirini içerdiğini savunan Bertell Ollman’ın da desteklediği üzere yabancılașmayı tarihsel materyalizmle birlikte düşünmemiz gerekir (2008:363). Marx’ın yabancılaşma kuramını soyutlayarak (örneğin geç dönem eserleriyle mutlak bir karşıtlık içinde) ele almak bu yüzden yanlış çıkarımlara yol açabilmektedir. 
insan zenginleştirdiği emeğinin ürününden yoksun olduğu için yabancılaşır. Marx, bu ilk boyutu, daha sonra yazacağı Kapitalde üretim araçlarının özel mülkiyeti teziyle geliştirecektir.

İkinci olarak Marx, yabancılaşmanın üretim sürecinde yaşandığını söyler. Bu boyutta, bir süreç olarak emek, insanın kendini özgürce var edeceği ve ifade edeceği bir alan değil, bir zorunluluk sürecidir. Yazara göre, şayet iş̧̧i ürününde yabancllaşıorsa, bunun nedeni üretim etkinliğinin kendisinin yabancılaşmış ya da yabancılaştırıcı olmasıdır. Bir başka ifadeyle, ilk boyut, ikinci boyuttan ileri gelmektedir. Marx, bu boyutta, etkinliğin gerçekleştiği çalışma koşullarına, işçinin etkinlik sırasında fiziki ve moral düzeyde yaşadıklarına ağırlık verir. Ona göre, işçilerin yaşadığ sefalet, yabancılaşma kavramının tanımlanmasında önemli bir yere sahiptir. ${ }^{4}$ Zira, sefalet, sadece açlık veya yorgunluk gibi maruz kalınan bir durum değil, genel anlamıyla etkinliğin öznel anlamda yaşanma biçimidir. S. Haber' in de belirttiği gibi sefalet, moral ve fiziki düzeydeki yaşamsal ihtimallerden mahrum olmaktır (2009). Bu nedenle Marx, yoksulluğu anlatırken parantez içinde, bahsettiğinin "maddi ve tinsel zenginlik ve yoksulluk" olduğunu belirtme gereği duymuştur (2011:99).

Yabancılaşmanın üçüncü ve dördüncü boyutu ise türsel bir yabancılaşmayı ve buna bağlı olarak insanin kendi türdeşlerine yabancılaşmasını ifade eder. Tür kavramında Feuerbach'tan esinlenen Marx, bu kavramı insanoğlunun durumunu ve insanlararası ilişkileri anlatmak için kullanır. $\mathrm{Bu}$ boyutta insan kendine yabancılaşır, genel anlamda hayatla olan ilişkisi bozulur. Burada, hayat kendinde amaç olmak yerine, bir araca dönüşür. Kendine yabancılaşma bu boyutta, diğer insanlarla kurduğu ilişkiye yansır ve bu ilişki türdeşlerine yabancılaşma şeklinde yaşanır. Dünya (toplumsal ve/veya fiziki anlamda) insana yabancı hatta düşman görünür.

$\mathrm{Bu}$ doğrultuda Marx için yabancılaşma, emeğin özgür olmayan biçimlerinde deneyimlenir ve yabancılaşmış emek belli tarihsel ve toplumsal koşullar altında ortaya çıkar. Ne var ki günümüz çağdaş siyaset felsefesi içinde yapılan tartışmalarda yabancılaşmaya pek fazla yer verilmemekte hatta yabancilaşma başka kavramlarla ikame edilmektedir. Eleştirel kuram; demokrasi, adalet ve iyi yaşam kavramlarını yabancılaşmanın yerine koymaktadır (Renault, 2006:105). Rawls’un özsayg kavramının Marx’ın yabancılaşma kavramına göre oldukça farklı bir karakteri olmasına rağmen açtığı tartışmalar, çoğulculuk endişeleriyle liberaller tarafından dışlanan bu ve benzeri kavramlara günümüz kapitalist sisteminin bireyler ve toplumlar üzerindeki etkilerini anlamak ve daha 'insani' bir yaşamı hedefleyen siyasi bir düşünceyi ortaya koyabilmek için ihtiyaç duyulduğunu göstermiştir. Bu doğrultuda bu çalışma, Rawls’un özsaygı kavramının Marx’n özellikle erken dönem yazılarında karşımıza çıkan yabancılaşma ile bağlantısı olup olmadığı, şayet varsa bu bağlantının nerede aranması gerektiği, iki kavramın farklılıkları, bu farklılığın ne ifade ettiği ve bu sorgulamaların çoğulculukla ilişkisini tartışmak üzere kaleme alınmıştır. Böyle bir çabanın, günümüz kapitalist toplumlarındaki yabancılaşmanın kaçınılmazlığını savunan görüşlerin aksine, insanın dünyadan yabancılaşmadığı bir toplum tahayyülü için gerekli olan bazı düşünsel araçları yeniden ele alması bakımından anlamlı olacağını umuyoruz.

4 Marx için işçilerin yaşadığı sefaleti betimlemek, kapitalist örgütlenmeyi anlamak için önemlidir. Keza daha sonraki eserlerinde de, işçilerin çalışma ve yaşam koşullarını uzunca betimler. 
Öncelikle yabancılaşmanın günümüz liberal eşitlikçi siyaseti içinde nasıl anlaşıldığı, çoğulculuk sorunları ekseninde nasıl ele alındığı değerlendirilecektir. Ardından Rawls'daki özsaygının, aslında üstü örtük bir yabancılaşma anlayışına dayandığı fikrini destekleyen Daniel Brudney'in görüşleri ekseninde, özsaygı kavramının Marx’daki yabancılaşmayla bağlantısı ele alacaktır. Çalışmamız özsaygı kavramının çoğulcu itirazlara yanıt olarak daha güçlü bir düşünsel araç sunup sunmadığına ilişkin bir tartışmayla sonlanacaktır.

\section{Yabancılaşma kuramına çoğulcu itirazlar}

Liberal çoğulcuların, yabancılaşma kavramına itirazları, kavramın tek bir 'iyi yaşam’ biçimine gönderme yaptığı yönündedir (Kymlicka, 2006). Gerçekten de kavramı, yabancılaşma durumlarını anlattığı için betimsel bir kavram olsa da örtük olarak daha iyi ya da yabancılaşmamış yaşam biçimleri olabileceğini varsaymaktadır. Ancak bazı çoğulcu itirazlarda dile getirildiği üzere yabancılaşmayı reddetmenin yalnızca tek bir iyi yaşam biçimini kabul etmek anlamına geldiğine katılmıyoruz. Bu eleştiriye cevap verirken yabancılaşma kavramını, çağdaş tartışmalar içinde konumlandırarak başlayabiliriz.

Marx, yabancılaşmayı kapitalist örgütlenmede, işçinin toplumsal bir etkinlik olan çalışma sürecinde, kendisiyle ve dünyayla yaşadığı bir deneyim olarak ifade eder (Renault, 2006:197). Bu anlamda yabancılaşma, bireyin kendisiyle ve dünyayla olan ilişkisindeki bir bozulma, karışıklık (disturbance) olarak algılanabilir. Bu durumun tam tersi olan dünyayı üretim aracilı̆̆ılla sahiplenme (appropriation) biçimi olarak yabancılaşmamış emek ise bireyin kendiyle, nesnel dünyayla ve diğerleriyle uyumlu bir ilişki (an appropriate relation) kurabilmeye yetkin olmasının temel koşuludur (Jaeggi, 2014). Bu doğrultuda yabancılaşma eleştirisi, bireyin dünyayı kendi dünyası olarak algılaması ve kendisini de bu dünyayı şekillendiren özne olarak algılamasının önündeki yapısal engellere yöneliktir. Dolayısıyla burada söz konusu olan, işçinin bir şeyden mahrum olması değil (bu şey emeğin ürünü olsa bile), bireyin kendisiyle ve dünyayla ilişkiye girebilme kapasitesinden mahrum olmasıdır (Haber, 2007). Bu yazıda önerdiğimiz yabancılaşma kavramı, öznenin nesneleşmış emekle olan karşıtlığını aşma çabasında olmayıp bu karşıtlığın kendisinin zaten yabancılaşmanın kuramsal sonucu veya ürünü olduğunu göstermek amacındadır (Fischbach, 2009). Başka bir deyişle yabancılaşma, ne bir kimlik kaybı ne de kendini dünyada kaybetmektir. Yabancılaşma esas itibariyle dünyanın kaybıdır. Bir nesneleşmeme (désobjectivation) süreci olarak yabancılaşma, bizi de facto dünyadan yoksun birakan sonsuz öznelleşme süreçleriyle bağlantılıdır (Fischbach, 2009:30). Yabancılaşma dünyaya yabancılaşma değil, dünyadan yabancılaşmadır. S. Haber' in tanımlamasıyla "yabancılaşmanın kurbanı olarak ben, 'kendimin' olanı kısmen kaybederim. Bir şeyi (bu durumda, beni hem aktif bir varlık, hem de nesnelerden etkilenen bir varlık olarak tanımlayan temel kuvveleri) kaybetmek ve bir daha harekete geçirememek, deneyimleyememek anlamında, bu şeyin benim muhtemel edimsellik alanımdan çıkması, başka bir şeye dönüşmesinden ötürü, normal-en iyi duruma nazaran, niteliksel olarak bir değişikliğe uğrarım, yani göreceli olarak bozulurum. [...] Yabancılaşmış 
ilişki, başkasıyla salt araçsal (instrumantal) ilişkilerden kurulu veya çevreleyen dünyaya sadece faydacı bir bakışla oluşmuş bozuk bir ilişki biçimi gibidir. Bu ilişki sosyal dünyayla kurulan her kusurlu münasebette tekrar ortaya çıkar ve bireyi zayıflatır." (Haber, 2009:9). ${ }^{5}$

$\mathrm{Bu}$ durumda yabancılaşma, kapitalizmin sonucu olmaktan çok, her defa yeniden üretilmesi gereken koşuludur: nesnelleşmiş emeğin (sermayenin), işçinin eyleminin gerçekleştiği bir nesnellik olarak görünmemesi için bu eylemin, emekten çoktan ayrılmış olması ve emeğin kendisini gerçekleştirecek nesnel koşullardan ayrı, basit öznel bir kapasiteye indirgenmesi gerekir. Zira, ontolojik emek kavramsallaştırması, hem dünyada olmamızın, ona dahil olmamızın vektörü hem de öznel bir kapasite olarak dünya yoksunluğumuzun şartıdır. Oysa kapitalist değer mantığına göre emek tekildir ve ancak bu mantık sonlandığında emek çoğulluğuna, çok biçimli yapısına kavuşabilir.

Yapılan bu tanımdan yola çıkarak, yabancılaşmanın, tek bir "iyi yaşam" biçimine gönderme yaptığı yönündeki eleştirilere cevap vermek gerekirse esas olarak yabancılaşma kavramının temel dinamiğini, tek yaşam biçimi eleştirisinden aldığını savunabiliriz. Bir başka ifadeyle, içinde yaşadığımız toplumsal örgütlenmenin dayattığı tek tip çalışma ve yaşama biçiminin betimlenip eleştirilmesi, bu kavramın temel görevidir. Çünkü toplumsal yapının teşvik ettiği özne, sadece seyircisi olduğu dünyadan bağımsız, o dünyada kendini tanımayan ve ona inanmayan bir öznedir. Yabancılaşmamış bir yaşam, tek bir 'iyi yaşam' idealine dayalı olmayıp, tersine emek süreçlerinin, dolayısıyla da yaşam biçiminin tekillikten kurtulup, çoğul yapısına kavuşmasını ifade eder.

Bir diğer çoğulcu itiraz, Marx’da "durgun ve tarih dışı bir insan anlayışının" (Petrovic \& Kohl, 2002:625) bulunduğunu ya da Marx’n özcü ve/veya idealist bir yaklaşıma sahip olduğunu öne sürer. ${ }^{6}$ Oysa Marx’n El Yazmaları'ndaki yabancılaşma anlayışı öncelikle antropolojiktir.

5 Alıntı Fransızca orijinal metninden yazarlarca çevrilmiştir.

6 Yabancılaşma kavramına bu bağlamda itirazlar sadece liberallerden değil, Marksizm içi yazarlardan da gelmiștir. En başat örneği L. Althusser'in Marx İçin (1996) adlı kitabında yaptığı tartışmadır. Marx’ın eserlerindeki gelişim ve değişimden yola çıkarak kendi özgün yapısalcı, anti-hümanist Marksizmini ortaya koyan Althusser, Marx’ın El Yazmaları'ndaki tarih ve insan anlayışındaki Hegel ve Feuerbach etkisini tartışır. Onun iddiası Hegel'in erekbilimsel (yani tarihi tinin mutlak bilgiye ulaşmasının yolu olarak gördüğü) tarih anlayışını Marx’n El Yazmaları̉nda antropolojik (ya da hümanist) bir tarih anlayıșıyla ikame ettiğidir. Böylece Marx için tarih, insanın yabancılaşmasının (ve yabancilaşmadan kurtulmasının) tarihi olarak ifade edilir (Althusser, 2003:238). Althussere göre Marx’ın ilerleyen dönemlerindeki çalışmalarında teleolojik bir tarih anlayışından bilimsel bir tarih anlayışına doğru epistemolojik bir kopuş (epistemological rupture) gerçekleşmiştir. Bu teze göre Marx, özellikle Alman İdeolojisi eserinden itibaren Althusser'in Marksizm öncesi (prémarxiste) ve bilimsellik öncesi (préscientifique) olarak adlandırdığ üç kavramla; insan özü/yabancılaşma/yabancılaşmış emek kavramlarıyla ilişkisini radikal biçimde kestiğini iddia eder. Yapısalcılar için Marksizmi böyle bir tarih ve insan doğası anlayışı içinde ele almak Marksizmin temel dayanağını oluşturan Marx’ın geç dönem tezleriyle bağdaşmayan idealist bir yaklaşımdır. Gerçekten de Marx’ın çalışmalarına yakından bakıldığında Althusser'in savunduğu üzere El Yazmaları'nın genç Marx’yla Grundrisse ve Kapital'in olgun Marx’ı arasında bazı farklıklar gözlemlenebilir. Ancak bu farklılıkların Marx’’ bir bütün olarak kavramayı imkânsız kılacak kadar derin olduğu iddiası, Marx’ın görüşlerinin zaman içinde tümüyle değiştiğini destekleyecek nitelikte değildir. Çünkü böyle bir iddiayı ileri sürebilmek için öncelikle Marx’ın çalışmalarının bütüncül bir okumasından yola çıarak varılan Marksizme ilişkin bir temelden söz edilmesi gerekir ki bu da kendi içinde çelişkili bir durumdur. Bu tartışmayı farklı boyutlarıyla ele alarak Marx’n tarih ve insan anlayışının değiştiğine dair savlar ileri sürmek ya da bu savları çürütecek şekilde Marx’ın bazı çalı̧malarını öne çıkartmak ve Marksizm için genel bir tutarlılık aramak elbette mümkündür. Althusser’in bu tezi, tüm radikalliğine rağmen yabancılaşma kavramını hümanist bir bakışla okuyup "bütünsel insan" (l'homme total) fikri çerçevesinde kısıtlayan bazı okumalardan ayrılması bakımından 
Kendinden ayrılma (séparation d’avec soi) fikri, temelde donmuş ve sabit bir kendilik olduğuna işaret etmemektedir. Zira Marx Feuerbach Üzerine Tezler'in altıncısında bu fikri eleştirir: "Feuerbach, dinsel özü, insan özüne indirger. Ama, insan özü, izole bireye içkin bir soyutlanma değildir. Esas itibariyle bu öz, toplumsal ilişkiler bütünüdür.” (1976) Şimdi, bu eleştiriden yola çıkarak bir yabancılaşma analizi yapabiliriz: Yabancılaşma, temelde tatmin etmeyen, sahiplenilemeyen, hatta katlanılamayan sosyal bir çevreyle karşılaşma sırasında ve sonucunda deneyimlenen kendiyle ve dünyayla olan bir ilişki biçimidir (Renault, 2006:97). Her şeye rağmen yaşadığımız (yaşamak zorunda olduğumuz) bu deneyim sırasında dünya ve kendi olma halimiz bize yabancı görünür.

Çoğulculardan gelen bir diğer eleştiri ise yabancılaşma kuramında, yaşam biçimleri arasında üstü örtük bir hiyerarşi olduğu, belli yaşam biçimlerinin insani gelişmeye daha fazla izin verdiği yönündedir. $\mathrm{Bu}$ eleştiriyi anlayabilmek için yabancılaşmanın semptomlarından yola çıkmak gerekir.

Lukes'e göre Marx, kendi yeteneklerini geliştirmeyi başarmanın her insanın uğraşı, hedefi ve görevi olduğuna, yabancılaşmış olan insanların insani özünü tatmin eden bir biçimde yaşamadıklarına ya da insanların çalışmalarının dışsal amaçlarının, bireylerin kendi tercihlerinden ziyade basit birer zorunluluk olarak göründüğüne inanıyordu (1998:58). Kapitalizmde yaşamın tek yanlı ve zorlayıcı bir karakteri vardır ve Marx’a göre kapitalizmin karşılıklı ilgisizliği körükleyen bu çatışmacı karakteri, ilişkileri fetişe benzeyen (1979) bir biçime indirger. Bunun anlamı kapitalizmde, insani olmayan, karmaşık, doğal olmayan ve hayali iştahların kabartılmasıdır (Marx, 2011). Kısacası kapitalist yöntemler emekçiyi, emek sürecinin zihinsel olanaklarından soyutlayarak "bir insan karikatürü biçiminde kötürümleştir" (Marx, 1986:645) ve neticede insan aşağılanmış, köleleştirilmiş, yüzüstü bırakılmış ve sefil bir varlık (Marx, 2011) durumuna gelir. Kapitalizmin tipik toplumsal ilişkileri ve kurumları (ücretli emek, meta mübadelesi, sermaye, para, vs.) bireylere kendileri dışında var olan, "kökenini ve hedefini bilmedikleri, dolayısıyla artık denetleyemedikleri, insanın iradesi ve eyleminden bağımsız olan bir dizi öznel aşamadan geçen yabancı bir güç olarak” (Marx, 1976) görünür (Lukes, 1998:113). Oysa komünizmde emek, Marx için yabancılaşmamış bir emektir ve çalışma zamanı ve etkinliği yabancılaştırıcı değildir.

Ancak çağdaş eşitlikçi liberalizm kapitalist bölüşüme alternatif, ideal dağıtımcı ilkeler peşinde

önemlidir. Ama yine de epistemolojik kopuş tezi, Marksizmi dar bir vizyonda ve fazla seçici bir okumaya maruz bırakma riskini taşır. Sean Sayers'in bu konudaki tartışmalara bakışı, İngilizce konuşulan dünyanın felsefecileri arasında şiddetli tartışmalara yol açan bu soruna 1980’lerde verilen kutuplaşmış yanıtların dışında kayda değer bir alternatif sunar. Bu tartışmalarda kutuplaşan görüşlerden biri “insan doğası” kavramının reddedilerek Marksizmin bir tür özcülük karşıtı, anti-hümanizm olarak anlaşılması gerektiğidir. Diğeri ise tersine, Marksizmin evrensel insan doğası kavramında ısrarcı olmasının, onun kuram olarak temelleriyle ve eleştirel değerleriyle daha uyumlu olduğunu savunur. Örneğin Norman Geras'in görüşleri bu yöndedir (Geras, 2009). Sayers, bu iki konum arasında sıkıştırılmayı reddederek, Marksizmin insan doğasına ilişskin Hegel'ci tarihsel bir açıklama içerdiğini, ancak bu açıklamanın geleneksel aydınlanma hümanizminden ve kuşkucu, olumsuz bir anti-hümanizmden farklı olarak, insan kapasitelerinin değişkenliğine yer bırakan dinamik bir yaklaşım olduğunun altını çizer (2013:21-22). İnsanlar maddi dünyayı şekillendirirken toplumsal ilişkilerini ve kendi doğalarını da dönüştürürler. Bu açıdan bakıldığında bireyler, liberal toplumsal düşüncenin varsaydığı üzere pasif, bireysel tüketiciler değil, aktif, toplumsal ve üretkendirler (2013:22). 
koşarken çoğu zaman kapitalist üretim ilişkilerini ve toplumsal ilişkileri verili olarak kabul eder.? Neoklasik iktisadın da amentüsü olan kaynakların kıt, ihtiyaçların sonsuz olduğu böyle bir dünyadan hareket ederek dağıtımcı bir adalet kuramının üzerine düşen, bu toplumsal kaynakların hakkaniyetli $(\text { fair })^{8}$ bir bölüşümünü düzenleyecek ilkleri belirlemektir. İdeal kuram çerçevesinde eşit vatandaşlar olarak bireylere düşen ise bu hakkaniyetli ilkeleri benimsemek ve bu ilkeleri kendi erdemi olarak benimseyen, dağıtımı gerçekleştiren kurumlara güvenmektir. Bu koşullar aslında bireylerin toplumsal kaynaklardan daha büyük bir payı daha az bir paya her zaman tercih ettikleri ve çalışmaktan çok (çalışma zamanının yabancılaştırıcı olduğu kabul edilir) dinlenceyi tercih ettikleri koşullardır.

Marx’n insani gelişim adına üretime yaptığı vurguyu kabul etmek zorunda olmadığımızı savunan liberaller için insani güçlerin kendi içinde amaçlar olarak gelişimi üretim dışında dinlence alanında da mümkündür. Richard Arneson da bu görüşü savunarak örneğin, insanların hayati gereksinimlerini karşılamak için hizmet odaklı işler yapan örgütleri ya da işyerlerinde çalışan gönüllülerin (iş̧̧ilerin), iş yeri demokrasisi gibi çalışanların kendini gerçekleştirebileceği koşulları iyileştiren öz yönetim mekanizmalarını "savurgan bir kendine düşkünlük olarak" (1987:526) değerlendirerek tercih etmeyebileceklerini savunur. Will Kymlicka, Jon Elster'den alıntılayarak (Elster, 1985:522), dinlencenin tüketimle ilişkilendirildiği, örneğin bir müzikseverin pahalı müzik aletlerine sahip olmak istemesinde ve bunun için yabancılaştırıcı işlerde çalışmayı yeğlemesinde de patolojik bir yan olmadığını savunur (2006:275).

Tüm bu eleştiriler aslında Kymlickảnın yazdığı üzere kimi insanların yabancılaşmamış üretken emeği hayatın temel isteği olarak göreceği, kimilerinin ise bedensel ve zihinsel sağlık, zihinsel becerilerin gelişmesi, hatta oyun, seks, arkadaşlık, sevgi ve din gibi değerleri tercih edeceği (2006:276) görüşünden türer. Bu yüzden yabancılaşmış emeğe getirilecek bir yasağın kimi insanlara adaletsiz bir ayrıcalık sağlayacağı düşünülür. Çoğulcular "neden ekonomik ilişkilerin maddi eşitlik konumundaki insanların ya da ideal adalet kuramlarının öngördüğü üzere toplumsal kaynakların hakkaniyetli bir şekilde dağıtılmış olduğu bir toplumdaki insanların özgür tercihlerine birakılmaması" gerektiğini sorgular (2006:278). ${ }^{9}$

Kymlicka yabancılaşma kavramının kaçınılmaz olarak belli bir insan özüne ve muhtemelen bu öze yakın olan belli bir yaşam biçimlerine gönderme yaptı̆̆ını düşünür. Dolayısıyla belli bir yaşam biçiminin özendirilmesinin, yaşam biçimleri arasında bir hiyerarşi kuracağından ve daha az değerli yaşam biçimlerinin de cezalandırılması gerekeceğini varsaydığından hareketle, yabancılaşma kavramının mükemmeliyetçi olduğunu iddia eder. Oysa liberaller, belli yaşam biçimlerini özendirmeden bireyleri, kaynakları en değer verdikleri biçimde kullanma konusunda

7 Aslında Rawls kendi ilkelerinin üretim araçlarının özel mülkiyetinin söz konusu olduğu bir toplumda olduğu gibi, liberal sosyalizm adını verdiği, üretim araçlarının işçilerin kolektif mülkiyetinde olduğu bir sistem için de geçerli olduğunu savunur. Bu iki toplum arasında bir seçim yapmadığının da altını çizer. Ancak bu ikinci sistemin de emeğin yapısı ve üretim araçları üzerinde olmasa da hala bir özel mülkiyet toplumu olması itibariyle Marx’n komünizmiyle aynı koşulları varsaydığı söylenemez. Bkz. Rawls, 2008, s. 187-194.

8 Rawls kendi kuramını hakkaniyet olarak adalet (justice as fairness) şeklinde formüle eder.

9 İtalikler bize ait. 
serbest bırakırlar (2006:271). Kymlicka, Marx’a göre insan olarak ayrıksı, yetkin yönümüzün özgür, yaratıcı işbirliğine dayalı üretim becerimizden geldiğini ifade eder. ${ }^{10} \mathrm{O}$ da kapitalist üretim biçiminde işlerin çoğunun bu açıdan doyurucu olmadığını kabul eder. Ancak bu, işçilerin yabancılaşmamış, yaratıcı ve özgür emeği değerli görseler bile başka değerler de söz konusu olduğu için var olan koşullar altında yabancılaşmış emeği tercih etmeyecekleri anlamına gelmez.

Kymlicka dile getirdiği bu eleştirilerde ve önerdiği yaşam biçimlerinde ${ }^{11}$ aslında üstü örtük bir yargıdan yola çıkar. Ona göre, her şeyden önce çalışma ve dinlence zamanı birbirinden bağımsız, hatta birbirine karşıt karakterdedir. Oysa, dinlenceye ayırdığımız, "boş zaman” olarak nitelendirilen zaman birimi modern bir kavramdır ve bu zaman birimi, temelde çalışmanın neden olduğu yıkıcı etkileri nötralize etmek adına araçsallaştırılmıştır. Kapitalizm öncesi dönemde, zamansallık kilise tarafından düzenlenirken, endüstri devrimi, emeğin anlam ve biçimini dönüştürerek zamanı kendi rasyonelliği üzerinden düzenlemiştir. R. Teboul'un da belirttiği gibi boş zaman ve çalışma zamanı ilişkinin rasyonelleşmesi, zamanın bireyselleşmesini doğurmuştur (2004:33). Dinlence ve eğlencenin zaman israfı olduğu yönündeki püriten ahlakın gerilemesi, isçi sınıfının tinsel anlamda gelişmesinden sorumlu olduğunu iddia eden dinin rasyonelleşmeye paralel olarak etkinliğinin azalması, sosyal hayatın ve boş zamanın düzenlemesinde boşluklar oluşturmuştur. Aynı dönemde, boş zamanı kullanmanın yeni yolları olan sinema gibi yeni eğlence biçimleri ortaya çıkmıştır. Boş zaman artık, ekonomik olanın operasyonel bir aracına dönüşmüştür. Daha sonraki yıllarda, özellikle birinci nesil Frankfurt Okulu yazarlarının kültür endüstrisi olarak kavramsallaştıracakları boş zaman kullanma ritüelleri ortaya konmuştur.

$\mathrm{Bu}$ sosyo-tarihsel açıklamadan yola çıkarak Kymlicka’nın eleştirisine cevap vermek istersek öncelikle yazarın "çalışma zamanı-boş zaman” ayrımının, zaten kapitalizme özgü bir ayrım olduğunu söyleyebiliriz. Açıklamada da belirttiğimiz gibi bu ayrım, maliyet-verimlilik anlayışı üzerine kurulu, rasyonel bir zaman ve tatmin arayışıyla biçimlenmiştir. Yazar bize, yöntemsel bireyciliğin (methodological individualism) ${ }^{12}$ önerdiği biçimiyle rasyonel bireyin, basit bir matematik formülüyle 4 saatlik çalışmada, yaşayacağı acının ve zorluğun, daha sonraki 2 saatlik tenis oynamasıyla telafi edilebileceğini iddia eder. Oysa daha önce de belirttiğimiz üzere, zaten

10 Marx hayvanların da iş birliği yaparak kendileri ve yavruları için yuvalar inşa ettiğini ancak insanın sadece kendisi için değil diğerleri, hatta hayvanlar için bile ürettiğini, bunu yaparken de kendini gerçekleştirdiğini yazar (2011). Ancak ahlaki bir bakış açısından yöneltilen eleştiriler insanın ayrıksı yönünün Marx’ın altını çizdiğiyle sınırlı olmadığını savunur. Örneğin Kai Nielsen şöyle yazar: “(...) suçluluk duygusuna sahip olmak, yabancılaşma ve acı kapasitesi, otomobil sürme, bir insanı ya da başka bir yaratığı karmaşık silahlarla katletme vb. kapasitesi de böyledir.” (Nielsen, 1973:23)

11 Buna benzer yaklaşımlar, özellikle Fransa’da Şanlı Otuz Yıl (Les Trente Glorieuses) olarak da bilinen II. Dünya savaşının ertesindeki otuz yıllık ekonomik büyüme döneminde kendisini Marksist ya da Marksçı olarak konumlayan başka yazarlardan da gelmiştir. Örneğin, P. Naville, gelişen teknoloji sayesinde, üretim de artacak bir makineleşmenin, insanların çalışma süresini düşüreceğini ve insanların boş zaman birimlerini arttıracağını ileri sürer. Naville’e göre, günde ortalama 2-3 saat sürecek yüksek verimlilikte bir üretim, ücretli kesimde bir dönüşüm sağlayacak ve bu sayede "toplum için etkinlik, toplum sayesinde yapılan etkinliğin sadece belli bir kısmını oluşturacak yani özgür, devingen ve çok görevli bir etkinlik” topluma egemen olacaktır (Naville, 1970:348).

12 Yöntemsel bireycilik, bütünden yola çıkan holizmden farklı olarak, sosyal bilimlerde açıklayıcılığını "bireyler arası etkileşimlerin oluşturduğu mikro sosyolojik süreçlerden” (Laurent, 1995:4) alan ve ilk defa açıkça 1940'da Hayek tarafından kullanılan bir yöntemdir. 
araçsallastırılmış rasyonel düşüncenin kendisi, bireyin dünyayı sahiplenmesi ve kendini o dünyada tanıyabilmesine engeldir.

İkinci olarak, yazar bireylerin çalışmayı tercih edip etmemesi noktasında, bir etkinlik olarak çalışmayı yine verili haliyle, yani iş gücü anlamında kullanır. Bu nedenle de toplumsal bir etkinlik olan çalışmayla, diğer toplumsal etkinlikler (eğlence, spor vs.) arasında bir hiyerarşi kurar ve çalışmanın esasen başka şeyler yapabilmek adına gerçekleştirilen bir özveri olduğunu ima eder. Oysa 1srarla belirttiğimiz gibi emek, bir özveri veya kendinden fedakârlık olarak değil, tüm çoğul anlamlarını bünyesinde bulundurarak var olan ve Marx’da antropolojik olarak tanımlanan bir kavramdır. Yazarın burada kullandığı çalışma kavramı ise, Marx’n El Yazmaları’nda dışsal emek olarak tanımladığı çalışma biçimidir: "Dişsal emek, insanın içinde kendine yabancılaştığ1 emek, bir kendini kurban etme, bir onur kırılması çalışmasıdır." Bu çalışma sürecinde "emek, dirimsel etkinlik, üretken yaşam, bunlar insana ancak bir gereksinmenin, fizik varlı̆̆ koruma gereksinmesinin bir karşılama aracı olarak görünürler” (2011:65-67). Kymlicka bu eleştirisinde, tekil anlamıyla, bir nesneleşmeme süreci olarak, emeği tanımlar ve bu nedenle de çalışmayı, dinlence karşıtı konumda görür. Zira çalışmadan söz ederken yazar, "mal üretmenin en verimli yolları" veya "bant üretimi" gibi kapitalist üretim modelinin kâr arayışındaki mantığının altını çizer. Bildiğimiz üzere, klasik anlamda bant üretimi, bireysel hareket alanı oldukça kısıtlı, özerklik ve özgür iradeyle karar verme marjı olmayan, zaman birim içindeki üretim kapasitesinin en yüksek düzeye ulaşmasını merkez alarak tasarlanan, modern bir mühendislik eseridir. Fordist üretimin banal bir görüntüsü olan bant üretimini, Marx’n bahsettiği anlamda toplumsal etkinlikte, kendiyle ve dünyayla olan ilişkinde yabancılaşması bağlamında yorumlamak kaçınılmazdır. Çünkü etkinlik artık öznenin kendisini var edeceği veya ifade edeceği bir alan/zaman değil, tersine varlığını inkâr edeceği, kendisini tanımayacağı bir alandır. Şüphesiz bu zorlama ve araçsallaşmış çalı̧̧ma karşısında kişisel tercihe dayalı, özgür iradenin hareket alanın en üst seviyede olduğu "tenis oynamak" gibi bir diğer toplumsal etkinlik çok daha çekici bir konumdadır. Yabancılaşma eleştirisi de tam bu noktada devreye girer. Bazı toplumsal etkinliklerde bireysel irade, otonomi ve kendini gerçekleştirme neden ve nasıl göz ardı edilir? Buna neden olan sosyal yapılar nelerdir? Bu durumun bireysel ve toplumsal yansımaları nelerdir?

Yabancılaşma kavramına çoğulcu anlamda getirilen bir diğer eleştiri ise Marx’n bireyin tercihlerini göz ardı ettiği yönündedir. Marx için kapitalizm, üretici güçlerin yabancılaşmayı doruğa ulaştıracak denli yoğunlaştığı özgün tarzda örgütlenmiş bir sistemdir. Bu yargıdan hareket ederek Marx’n kapitalizmdeki yabancılaşmayı besleyen faktörlerin ortadan kalkacağını düşündügü komünizmde yabancılaşmanın ve kendini gerçekleştirme önündeki engellerin artık var olmaması gerektiği şeklinde sistematik bir okuma mümkündür. Çoğulcu eleştiriler, yabancılaşma kuramı içindeki kendini gerçekleştirme idealinin bireyin tercihleri açısından sorunlu olduğu fikrinden yola çıkar. Bu bağlamda yapılan eleştirilere cevap verebilmek adına Marksizmi yeniden "anlamlı kılma" iddiasında olan analitik marksistler ${ }^{13}$ yöntemsel bireyciliği

13 Analitik Marksizm 1970'li yılların sonlarında iki yılda bir bir araya gelmeye başlayan "September Group" olarak da anılan bir grup akademisyen tarafından kurulan bir Batı Marksizmi ekolüdür. Birçok konuda görüşleri birbirinden 
benimseyerek Marksizmi yeniden yorumlar. Ancak böyle bir yaklaşımın bedeli yabancılaşma kuramına sırtını dönmek olmuştur.

Kendini analitik marksist olarak konumlayan Jon Elster’in Marksist kendini gerçekleştirme (selfrealization) idealine itirazları çağdaş siyasi tartışmalar içerisinde önemini korumaktadır. Elster, kendini gerçekleştirme idealinin Marksist düşünce içerisinde bir güçlü, bir de zayıf yorumu bulunduğunu savunur (1999:522). Her iki şekilde de okunabilecek kendini gerçekleştirme, güçlü yorum söz konusu olduğunda komünizmde bireylerin tümünün diğerlerinin sahip olduğu yetilerin tamamına sahip olacağı ve bu yetileri kullanarak geliştireceği düşüncesine dayanır. Bireylerin tümünün bu kapasitelere sahip olacağını düşünmek Elster’e göre örneğin genetik faktörler hesaba katılmadığı için oldukça ütopiktir. Elster bir toplumda her bireyin aynı kendini geliştirme potansiyeline sahip olamayacağının altını çizerken, örneğin engelli bireylerin durumunu düşündüğümüzde, elbette haklıdır. Ancak tüm bireylerin çok farklı özelliklere ve yetilere sahip olmadığ gerçeğini kabul etmemiz bu bireylerin hiçbir kendini gerçekleştirme potansiyeline sahip olmadığı anlamına gelmez. Genetik faktörler de dahil olmak üzere tüm şansa dayalı faktörlere rağmen bir toplumun bireylerinin neredeyse tamamının belli bir kendini gerçekleştirme potansiyeline sahip olduğunu kabul etmemiz gerekir. Sadece fiziksel ya da zihinsel kapasiteler anlamında daha talihsiz bireylerin bu potansiyelleri kullanabilmek için daha fazla toplumsal kaynağa ve desteğe ihtiyacı vardır. Elster'e göre zayıf yorumda ise kendini gerçekleştirme yerine özgürlüğe vurgu yapılır. Bu vurgu gücünü komünizmde bireylerin herhangi bir etkinlik konusunda kendilerini gerçekleştirmelerine hiçbir engel olmayacağı görüşünden alır. Elster böyle bir uğraşın da çeşitli toplumsal koordinasyon sorunlarını beraberinde getireceğini savunur (1999:522). Elster kendini gerçekleştirme idealinin çoğulcu değerler karşısında sorunlu bir konuma düştüğü konusunda Kymlicka ile buluşarak eleştirilerini sürdürür:

"Kendini gerçekleştirme ideali büyük çaba isteyen bir idealdir. Acaba fazla mı talepkârdır? Komünizm (...) pasif tüketim zevklerini tercih edenleri dışlamal ya da damgalamal mıdır? Kaynakların üretim sürecini teşvik edecek biçimde dağıtılması üretmekten ziyade üretimin meyvelerinden istifade edenlere haksızlık olmaz mı? Bu konuda bazı endişelerim olduğunu itiraf etmeliyim. Çağdaş toplumlarda birçok insanın pasif yaşamlarını göz önünde bulundurduğumda bunun çoğunlukla aslında bertaraf edilebilir toplumsal sebepleri olduğunu düşünürüm. Ancak bunun asla özgür bir tercihin ürünü olamayacağ konusunda emin değilim. Herkesin yeterli zaman, enerji, para ve öz bilince sahip olduğu

\footnotetext{
ayrılsa da analitik marksistler için öncelikli hedef Marksizmi içinde barındırdığı "hurafelerden” temizlemekti. Gerald A. Cohen, John Roemer, Jon Elster, Philippe Van Parijs gibi düşünürlerin katıldığı bu toplantılarda farklı yöntemler ve yaklaşımlar kullanılarak sosyal bilimlerin farklı alt disiplinlerinin araçlarıyla Marx’ın ve devamcılarının kuramları ele alınıyordu. Gerald A. Cohen'in 1978'de yayımlanan Karl Marx's Theory of History: A Defence adlı çalışmasının kurulmasına zemin hazırladığı ekol, genel olarak Marx’n kuramlarının artık modern sosyal bilimlerin çatısı altında kabul edilebilir bir zemini kalmadığından hareketle modern sosyal bilimlerin (öncelikle Anglosakson bilim dünyasında kabul gören) araçlarıyla gözden geçirilmesini hedefliyordu. Bu çerçevede Marx’ın kuramlarının örneğin, akılcı tercih kuramı (rational choice theory) ya da yöntemsel bireycilik gibi analitik açıklayıcılığa, kesinliğe ve ispat edilebilirliğe sahip olduğu düşünülen yöntemlerle yeniden ele alınması öngörülmüştü. Fakat yaklaşımlarını "saçmalık olmayan Marksizm" (non-bullshit marxism) olarak adlandıran analitik marksistler, gelinen noktada Marksizmin temelini oluşturan tezlerden o denli uzaklaşmışlardır ki yine Analitik marksistlerden sayılan John Roemer, analitik marksistlerle sol liberal eşitlikçiler arasındaki sınırın son derece belirsiz olduğunu itiraf eder (1986:200).
} 
durumlarda bile herkesin üretimi tüketime yeğleyeceğinden şüpheliyim. Söz konusu bireyler dışında buna kimsenin karar verebileceğini de düşünmediğim için bu belirsizliğin kendini gerçekleştirme idealinin yerine getirilmesinde tedbirli olmayı gerektirdiğini düşünüyorum. (...) Ayrıca kendini gerçekleştirme ideali kendini hoş görmeye ve narsisizme kolaylikla evrilebilir. (...) Bireylerin kafasında kendini gerçekleştirme fikri değil yaptıkları işlere ciddiyetle odaklanmak olmalıdır. Kendini gerçekleştirmenin hazzı ardından gelecektir. (...) Sürekli olarak kendini gerçekleştirmeyi planlamak olması beklenin aksine yıkıcı olabilir." (1985:522-523)

Elster'in kendini gerçekleştirme fikrini performans odaklı olarak düşündüğü anlaşılmaktadır. Ancak Marx’n komünist toplumunda bireylerin kendini gerçekleştirme konusunda takıntılı olduğunu varsaymamız için bir neden yoktur. Böyle bir toplumun kendini gerçekleştirme üzerinden rekabete giren bireylerden oluştuğunu varsaymak Marx’ın komünist toplumunu günümüz hâkim bireysel motivasyonlarından yola çıkarak yorumlamak olur. Oysa Marx’ın komünizminde "var olan sıra dışı iş birliği, her bireyin, 'dışsal' olarak düşünülen dünyayla kurduğu ilişkilere dair geliştirdiği anlayış tarzında bir devrim" (Ollmann, 2012:182) niteliğindedir. Çalışma ve yaratıcılık gibi insani etkinliklerin diğer insanlarla ve diğer insanlar için olduğu bu toplumda, bireyin etkinliğinin çeşitliliği ve yoğunluğu, onu doğrudan ya da toplumun bir birimi olarak dolaylı yoldan doğanın tümüyle temasa geçirir (2012:182). Aksine emeğin kaçınılmaz olarak kendini gerçekleştirmeye engel olan zorlayıcı biçimlerde var olduğunu ve gelecekte de öyle olacağını savunan Elster için yabancılaşmadan kurtulmak imkansız görünmektedir:

"Modern sanayi toplumlarında iş, Marx’ın aklındaki gibi bir kendini gerçekleştirmeye pek az imkan tanır. Tekrar edici, monoton ve sıkıcı olabileceği gibi, özgür, yaratıcı emeği ciddi bir biçimde kısıtlayan koordinasyon koşulları ve denetimi gerektirir. Elbette gelecekte alternatif teknolojiler bu durumu geçen yüzyıla kıyasla muhtemelen iyileştirecektir ancak bu durum tamamen bertaraf edilemez." (1985:523)

Görüldüğü üzere Elster de kendini gerçekleştirmeyi günümüz kapitalizmi için geçerli koşullarda düşünür. Elbette Elster'in eleştirilerinden bazıları Marx’ın komünizmi söz konusu olduğunda geçersiz kalmaktadır. Ancak Elster, Marx’dan farklı olarak komünist toplumun da bir bolluk toplumu olmayacağını ve farklı kullanımlara hizmet eden kaynakların yine kısıtlı olacağını (i), Marx’’n komünizm kuramındaki dağıtımcı adalet ilkesinin eşit kendini gerçekleştirme ilkesi olduğunu (ii), kendini gerçekleştirme biçimleri arasında yapılacak özgür tercihlerin çoğunlukla daha pahalı kendini gerçekleştirme biçimlerine yöneleceğini (iii) savunur (1985:524). $\mathrm{Bu}$ nedenle Marksist kendini gerçekleştirme idealine yönelttiği eleştirileri de buradan yola çıkarak değerlendirmek gerekmektedir. Elster ilk öncülün (i) ve dolayısıyla ikinci öncülün (ii) reddedilmesi durumunda zaten gerçekçi olmayan, her şeyin mükemmel olduğu bir durumda (cloud cuckoo land) olacağımız için tartışmaya gerek olmadığını savunur. Üçüncü öncülün (iii) reddedilmesi ise insanların toplumun yararı, yani diğerlerinin kendini gerçekleştirebilmesi adına bazı kendini gerçekleştirme imkanlarından feragat edeceği anlamına gelir. Bu da aslında çok ileri bir diğerkamlık biçiminin gelişmiş olması demektir ancak bu Marx’ın toplumda herkesin hep birlikte tam olarak kendini gerçekleştirebileceği düşüncesine aykıııdır (1985:524). 
Elster'in kendini gerçekleştirme idealine yönelttiği eleştiriler bunlarla sınırlı değildir ancak bu eleştirilerden çoğulcu itirazlar bağlamında ele alınabilecek olanları incelemiş bulunmaktayız. $\mathrm{Bu}$ eleştirilere cevap verebilmek için yabancılaşma analizine paralel bir şekilde, kendini gerçekleştirme söylemini idealist değil, realist ve hatta pragmatik bir düzlem üzerinden okuyarak marksist anlamda kendini gerçekleştirme ile Elster'in yorumladığg kendini gerçekleştirme söyleminin farklılıklarına dikkat çekebiliriz.

Kendini gerçekleştirme deneyimini herhangi özcü bir söyleme yer bırakmadan değerlendirmek için altı çizilmesi gereken nokta, gerçekleştirilen kendi olma halinin verili, donmuş ve sabit olmadığ kurduğu özdeşleştirici ilişkide ve onların süregeldiği dünyayı sahiplenmede (1'appropriation du monde) söz konusu olan bir deneyim olduğudur. "Birey kendini dünyada ve dünyaya göre biçimlendirir, kendine ancak dünya aracılığıyla döner” (Jaeggi, 2009:103). ${ }^{14}$

Jaeggi’ye göre kendini gerçekleştirme gereksinimi, temel dayanağını gerçekleştirdiğimiz etkinliklerin, bizim tarafımızdan seçilmiş olması koşulundan alır. Kendimizi ancak kendi irademizle seçtiğimiz etkinliklerde gerçekleştiririz. Bu irade iki biçimde ortaya çıkar; öncelikle etkinliğin seçilmesi ve/veya gerçekleşmesi aşamalarında herhangi zorlayıcı bir güç olmaması, ikinci olarak da etkinliğin herhangi dış bir amacın aracı değil, "kendinde amaç" olmalısı halinde (Jaeggi, 2009:105). Bu bağlamda yabancılaşma deneyimi, yaşam biçimlerinin kendinde amaçlar olarak mı yoksa araçsal biçimler olarak mı yaşandığına göre tanımlanır.

Buradan yola çıkarak, yabancılaşma eleştirisinin aslında modernitenin temel prensiplerinden olan özgür iradenin yokluğuna paralel olduğu ileri sürülebilir. Bilindiği üzere aydınlanmacı anlamda Batı modernitesi akılcılık, hümanizm, bireysellik prensiplerinin doğuracağı özgürleşim (emancipation) ve kendini gerçekleştirme vaatleri üzerine kuruludur (Rosa, 2012). I. Kant, Aydınlanma’yı, insanın kendi suçu ile düşmüş olduğu bir ergin olmama durumundan kurtulması olarak değerlendirir. "Bu ergin olamayış durumu ise, insanın kendi aklını bir başkasının kılavuzluğuna başvurmaksızın kullanamayışıdır.” (2012) Yani modernite fikri, özgürlüğü ve özgür iradeyi temel değerleri olarak belirlemiştir. Oysa daha Marx’nn El Yazmalari'ndan itibaren görürüz ki yabancılaşma eleştirisi, modern toplumsal patolojilere yöneliktir. ${ }^{15}$ Dolayısıla bu bağlamda yapılacak bir eleştiri, modernitenin kendine içkin çelişkilerini ortaya koymak anlamında da önemlidir ve yine çoğulcu söylemlerin felsefi dayanağı olan Aydınlanmacı söylemin gerçekleştir(e)mediklerine bir cevaptır.

Şimdi, Elster'in anladığı biçimde "kendini gerçekleştirme"yi analiz edebiliriz. Öncelikle yazar, üretim etkinliğini tüketim etkinliğinden tamamen bağımsız ve karşıt olarak değerlendirir ki bu Marx’ın "meta fetişizmi” kavramıyla tanımladığı, kapitalizmin yaratmak istediği illüzyonun kendisidir. Dolayısıyla bu iki etkinliğin bireyin iki farklı dünyasına seslendiği gerçeği, bugünün

14 Alıntı Fransızca orijinal metninden yazarlarca çevrilmiştir.

15 Bu kullanım özellikle birinci nesil Frankfurt Okulu yazarlarınca doruğuna çıkar. Bkz. E. Fromm, 1982, H. Marcuse, 1968, T. W. Adorno, 2005. 
toplumlarına içkin ve Marx’ın eleştirdiği bir toplumsal algıdır. Bu ayrımdan yola çıkan yazar, kimi bireylerin, "pasif tüketim tercihleri" olabileceğini ve kendini üretimden ziyade, tüketim alanında gerçekleştirmeyi tercih etmelerini anlayabileceğini söylüyor. Bu noktadan itibaren, Elster’in bahsettiği kendini gerçekleştirme deneyiminin, aslında hedonist tüketim kültürünün öne çıardığı, bireysel tatmine dayalı bir deneyim olduğunu anlarız. Burada bahsedilen kendini gerçekleştirme, narsisizm kültürüyle beslenen, ben merkezli bir şekilde, Adorno’nun da belirttiği üzere "çiçek açmak için sürekli sulanması gereken bir bireyin yetiştirilmesi” (2005:164) şeklinde algılanmaktadır.

$\mathrm{Bu}$ nedenle yazar, kendini gerçekleştirmeyi bireyin kafasındaki bir ideal olarak görür ve bireyin kafasında kuracağı planlarla gerçekleşeceğini, sonucunda bireye haz vereceğini, bu nedenle de belli durumlarda zararlı bile olabileceğini iddia eder. Oysa bizim tanımladığımız şekliyle kendini gerçekleştirme bireyin kafasında planlayarak gerçeklesen bir şey değil, sosyal süreçlerin toplamıdır. Yani, kendini gerçekleştirmek için, bireyin sürekli kendine yatırım yapıp idealize ettiği bir kendiliğe ulaşmak için performans göstermesi söz konusu değildir. Kendini gerçekleştirme, sürekli olarak bir şeyleri gerçekleştirmek ya da "içsel" anlamda bir büyüme ve gelişme olmak yerine, yaptıklarımızda (sosyal etkinliklerimizde) kendini gerçekleştirmek anlamında etkin olma halidir. Bir başka deyişle pasif değil aktif bir deneyimdir (Jaeggi, 2014). Bize göre kendini gerçekleştirme, özgür iradeyle paralel giden bir varoluş yapısıdır.

İkinci olarak, yazar modern toplumlardaki iş örgütlenmelerinin kendini gerçekleştirmeye imkân tanımadığını söyler ve gelecekte teknoloji gelişse bile durumun tamamen iyileşmeyeceğini ileri sürer. Yazar burada monotonluk ve sıkıcilığın işin kendi doğasından kaynaklandığını iddia etmektedir. Oysaki daha önce de belirttiğimiz üzere modern toplumlarda iş organizasyonu kâr merkezli bir toplumsal örgütlenmeyi öngördüğü için emeğin kısıtlanarak koordine edilmesi ve denetlenmesini gerektirir. İşin doğasına içkin bir sıkıclıktan ziyade, amacın belirlediği, yöntemsel bir monotonluk söz konusudur. Dolayısıyla tek başına teknolojinin gelişmesi, bu durumu bertaraf edemez. Hatta tersine, teknoloji, post-fordist ve post-taylorist üretim biçiminde görüldüğü üzere, çalışma koşullarının ağırlaşması pahasına (just-in-time üretim, performans kriterleri, esnek çalışma biçimleri vs.) göreli artı değeri arttırmanın aracı olur.

\section{Yabancılaşma ve özsaygı}

Marx’n kendini gerçekleştirme kavramıyla yabancılaşma kavramının kesiştiği yerde yabancılaşma, bireyin kendini gerçekleştirmesi önünde önemli bir engel olarak tanımlanabilir. Dolayısıyla yabancılaşmanın, insanı özgür ve yaratıcı gelişimin koşullarından uzaklaştırdığı, mutsuz, körelmiş ve güçsüz bir hayata mahkum ettiği söylenebilir. Benzer biçimde, Rawls’da da bir toplumda iş birliğinin sonucu olarak elde edilen toplumsal kaynakların ve o toplumdaki yüklerin, sorumlulukların dağılımdaki adaletsizliğin bireylerin özsaygısını zedelediği düşüncesine rastlarız. Ayrıca Marx’ın insan doğası anlayışına benzer olarak Rawls da "bireyi hem belirli insani kapasitelerin gerçekleştiricisi olarak, hem de özerk bir amaçlar seçicisi olarak görür” (Peffer, 2001:367) ve yine her iki düşünür için de bu insani kapasitelerin gelişmesi ve insani etkinliklerin anlamlı olması ancak topluluk içinde mümkündür. Bu açlardan bakıldığında Marx’ın 
yabancılaşma kavramıyla Rawls’un özsaygı kavramı arasında bazı bağlantılar sezinlenebilir. Ancak iki kavramın bağlı olduğu iktisadi ve siyasi görüşler düzleminde bazı önemli farklılıklar da söz konusudur.

John Rawls'un kuramı öncelikle iyi düzenlenmiş (ideal) bir toplumun (well-ordered society) dayanağını oluşturan genel bir kurallar sistemini ifade eden temel yapıyı (basic structure) tanımlamayı amaçlar. Ancak bu öncelikle toplumsal adaletin başka bir ilke uğruna kesinlikle feda edilmeyeceği şekilde yapılmalıdır. Bunun için Rawls, bir toplumda temel toplumsal kaynakların hakkaniyetli bir biçimde dağıtılmasını sağlayacak, öncelikle kurumların erdemi olan adaletin ilkelerini belirler. Rawls’a göre bu ilkeler, aynı zamanda başlangıç konumu (original position) adını verdiği kurgusal bir eşitlik konumdaki bireylerin, üzerinde hemfikir olacağı ilkelerdir. Rawls’un kuramının sözleşmeci yönüne işaret eden bu kurgusal eşitlik konumunda bireyler, kurulacak toplumda kaynakların dağılımını belirleyecek olan adaletin ilkeleri üzerinde anlaşmak için bir araya gelirler. Bireylerin bilgisi, "tarihin ve insan doğasının genel olguları dişında" (Peffer, 2001:286) kaynaklardan alacakları pay ve konumları konusunda bilgi sahibi olmalarını engelleyen bir cehalet peçesiyle (veil of ignorance) sınırlandırılmıştır. Böylece bireyler, kurulacak toplumda örneğin, ne kadar zengin ya da fakir olacaklarını veya hangi mesleği icra edeceklerini bilemezler. Böyle bir noktada Rawls, oyun kuramlarının sosyal bilimlere kazandırdığı akılcı tercih (rational choice) yaklaşımından yola çıkarak, bireylerin söz konusu toplumda, ilkin temel hak ve özgürlükleri herkes için garanti altına alacaklarını savunur. Sonra da kurulacak toplumda bireylerin (kendilerinin de en dezavantajlı durumda olan bireyler olabileceklerini düşünecekleri için), toplumsal konumları ve meslekleri hakkaniyetli bir şans eşitliği uyarınca herkese açık hale getirecek ve öncelikle en dezavantajlı durumda olacak bireylerin durumunu iyileştirecek şekilde düzenleyen ilkeler, yani kendi kuramının ilkeleri üzerinde hemfikir olacağını savunur. Ancak Rawls, başlangıç konumundaki bu bireylerin, adaletin ilkelerini yalnızca akılcı hesaplar sonucu uzlaşılabilir bir optimum nokta olarak gördükleri için değil, aynı zamanda bireylerin iyi düşünülmüş yargılarıyla (well-considered judgements) örtüşerek adalet duygusunu tatmin ettiği için de seçeceklerini savunur. Rawls böylece kuramında ilkelerini ikinci bir yönden de destekleyen sezgici bir teze yer açar. ${ }^{16}$ Fakat aynı ilkeleri desteklese de bu ikisinin farklı tezler olduğunu unutmamak gerekir. ${ }^{17}$

16 Yansıtıcı denge (reflective equilibrium) tezi bir bireyden yola çıkar. Rawls, Rousseau'dan esinlenerek, bireyleri oldukları gibi kurumları ise olması gerektiği gibi ele almak gerektiğini savunurken bireyleri genel veya ayrıntılı ahlaki yargılara varabilme yetileriyle tanımlar. Bu yetiye, imkâna ve isteğe sahip bir birey, içsel ahlaki çelişkilerin bir an için üstesinden gelerek adalet üzerine iyi düşünülmüş yargılara (örneğin A. Lincoln’ün kölelik bir haksızlık değilse başka hiçbir şeyin haksızlık olmadığını söylemesi gibi) varabilir. Bireyi, bu iyi düşünülmüş yargılarıyla toplumsal sözleşmeden çıkan adaletin ilkeleri arasında bir uyum arayışı içerisinde düşündüğümüzde uyuşma sağlanamıyorsa sözleşmenin koşullarının gözden geçirilmesi ya da bireyin yargılarını gözden geçirmesi söz konusu olur. İște Rawls, benzer yargılarımızın adaletin ilkleriyle uyumlu hale gelmesi durumunu yansitıcı denge şeklinde ifade eder. $\mathrm{Bu}$ anlamıyla yansıtıı denge, sözleşmeyi her biri toplumsal kaynaklardan daha fazla payı daha azına tercih eden akılcı bireylerin sadece razı oldukları bir durum olmaktan kurtararak adaletin ilkeleriyle bireylerin adalete ilişkin ahlaki yargılarını çarpıştıran vicdani bir sağlama görevi görür. Rawls’un yansıtıcı denge kavramını açıkladığı bölümler için bkz. (2005:17-22; 2008:52-56).

17 Hatta Peffere göre, Rawls'un ilkeleri yalnızca sezgici tezden destek alınarak da savunulabilir (Peffer, 2001, s.288). Kymlicka da aynı Peffer gibi Rawls’un kuramının güçlü yanının aslında sezgici tez olduğunu, başlangıç konumunun kurama savunulabilirlik açısından pek de faydası olmadığını düşünür (Kymlicka, 2006:97). 
$\mathrm{Bu}$ ilkelerin seçilerek uygulanması ahlaki bakımdan doğru, oldukça akılcı, mantıklı olabilir. Ancak bütün bunlar yine de adaletin, ilkeler düzleminde tartışılarak toplumun temel yapısına uygulanmasının neden mümkün ve gerekli olduğunu açıklamaz. Rawls’a göre toplumlar genel olarak karşılıklı çıkar adına yapılan iş birliği girişimleri olarak ifade edilebilir. Fakat bir toplum çıkar birliğiyle olduğu kadar çıkar çatışmasıyla da şekillenir. Herkesin tek başına çabalayarak elde edebileceğinden daha iyi bir hayat vaat ettiği için toplumsal iş birliği bir çıkar birliğini ifade eder. Ancak bireylerin yapılan iş birliğinin meyvelerinin nasıl dağılacağ konusunda kayıtsız olmamaları, yani amaçları uğrunda her birinin daha büyük bir payı daha küçüğüne yeğlemesi de çıkar çatışmasını ifade eder (Rawls, 2005:126). Fakat Rawls, ideal kuramının gerçekçi bir düzlemde kabul edilebilir olmasını öncelikle bu iş birliğini mümkün kılan adaletin koşullarına (circumstances of justice) bağlar. Bu koşullardan nesnel olanı, kaynakların iş birliğini lüzumsuz kılacak denli bol olmadığ ancak koşulların da olumlu iş birliği doğrultusundaki girişimleri başarısızlı̆̆a mahkum edecek kadar zor olmadığı, göreli nedret durumudur (2005:126). Öznel koşullar ise iş birliği yapan tarafların niteliğiyle ilgilidir. İş birliği yapan tarafların bazı ortak ihtiyaçları ve çıkarları olsa da kendi projeleri ve kendi iyi anlayışları vardır. Bu onları var olan doğal ve toplumsal kaynakların kullanımı konusunda çatışmalı amaçlar edinmeye götürür. Taraflar bu amaçlarına ulaşmak istedikleri kadar amaçlarının ve buna bağlı olarak iyi anlayışlarının da diğerleri tarafından kabul görmesini (tanınmasını) isterler (2005:127).

$\mathrm{Bu}$ fikirler özsayg1 kavramılla bağlantılıdır. Rawls toplumsal kaynaklardan birinin, hatta en önemlisinin, bireylerin kendi iyi anlayışlarının ve yaşam projelerinin peşinden gitmeye değer olduğuna derin bir inanç beslemesini sağlayan özsaygı olduğunu savunur (2009:440). Bu anlamıyla özsaygı bireye, imkânlar dahilinde niyetlerini gerçekleştirme yetilerine güven tesis eder. Özsaygı olmaksızın yaşam projelerimizin peşinden gitmekte ve bunları gerçekleştirebilsek dahi tatmin olmakta zorlanırız. Bunun için başlangıç konumundaki taraflar özsaygının altını oyan toplumsal koşulları bertaraf etmeye çalışırlar (2005:440).

Çoğulcu eleştirileri dikkate alan Rawls daha sonra öznel bir durum olarak özsaygı yerine toplumsal bir kaynak olarak özsaygının toplumsal temellerini kastettiğini belirtir. ${ }^{18}$ A Theory of Justice'de bu ayrımı görmesek de Rawls, Aristotelesci bu ilkenin yalnızca yüksek sanatsal, bilimsel ya da toplumsal ortak amaçlara yönelmek konusunda istekli ve yetenekli kısıtlı bir topluluk için geçerli olmadığını, ilkenin bireye, bireyin doğal yeteneklerine ve özgün durumuna göre nispi bir niteliği olduğunu savunarak çoğulcu bir bakış açısını yansıtır. İyi düzenlenmiş bir toplumda bireyler irili ufaklı topluluklar, dernekler ve farklı birliktelikler halinde bir araya gelerek kimileri tarafından yüksek niteliğe sahip görülsün görülmesin, kendileri için anlamlı etkinliklerde bulunurlar (2005:441). Rawls için başlangıç konumunda olduğu gibi, iyi düzenlenmiş bir toplumda da

18 Rawls Justice as Fairness'de özsaygı kavramına ilişkin olarak önemli bir düzeltme yapar. Öznellik ve nesnellik konusundaki ayrıma denk düşen bu düzeltme $A$ Theory of Justice'nin özsaygıyı bir tutum olarak mı yoksa bu tutumu takınmamızı sağlayan toplumsal temeller olarak mı anlamamız gerektiği konusunda muğlak kaldığı için gerekli görülmüştür. Bu çalışmasında Rawls bir toplumsal kaynak olanın ilki değil, ikincisi olduğunun altını çizer. Bu nedenle Rawls bu eserinde bir toplumsal kaynak olarak özsaygının toplumsal temellerinden söz eder. Bu toplumsal temeller vatandaşlara eşit temel haklar sağlayan kurumsal çerçeve, bu olgunun ve bir karşsllkllılık biçiminin ifadesi olan, herkesin fark ilkesini onayladığının kamusal olarak tanınmış olmasıdır (2008:59). 
bireylerin benimsedikleri bu ilke mükemmeliyetçi olmaktan uzak, tanınma odaklıdır (2005:442).

Böyle bir yaklaşımın özsaygı kavramını çoğulcu bir perspektife yerleştirdiğini düşünebiliriz. Ancak toplumsal kaynak olarak özsaygıyı değil de özsaygının toplumsal temellerini kabul etmek neyi değiştirir? Bireylerin irili ufaklı topluluklar halinde anlamlı etkinlikler içinde olduklarını varsaydığımızda bunun yeterli olacağını düşünmemiz için bir sebep yoktur. Modern toplumlar, iç içe geçmiş topluluklardır ve etkinliklerinin sadece kendi içlerinde değil diğer topluluklar tarafından da anlamlı bulunmasını, kabul görmesini isterler. Rawls toplulukların değer görmek istiyorlarsa iyi anlayışlarının adaletin ilkeleriyle uyumlu olması gerektiğini düşünür. Ona göre iyi düzenlenmiş bir toplumda adaletin ilkeleriyle uyumlu bütün Aristocu ilkeler kabul görür. Ancak yine de gerek çağdaş toplumlarda gerekse Rawls’un ideal iyi düzenlenmiş toplumunda bir değerler hiyerarşisi olmadığını ya da olmayacağını düşünmemiz için bir sebep yoktur. Öyleyse bireylerin ya da toplulukların hangi değerlerle bağdaşan etkinlikleri tercih edecekleri yalnızca onların tercihlerine ve özelliklerine bağlı değildir. İyi düzenlenmiş bir toplumda dahi bir değerler hiyerarşisi üreten, bireyleri ve toplulukları yönlendiren, örneğin bireylerin ve toplulukların özelliklerini ve tercihlerini uyarlayan çeşitli mekanizmalar söz konusudur. ${ }^{19}$ Rawls özsaygının toplumsal temellerinden söz etse de bu temellerin altını oyan mekanizmalardan hiç söz etmez. Marx ise yabancılaşma kavramını eleştirel bir zemine oturtarak yabancılaşmayı üreten mekanizmaları deşifre eder.

Daniel Brudney, yabancılaşmadan hiç söz etmeyen Rawls’un özsaygı düşüncesinin altında örtük bir yabancılaşma kuramı yattığını savunarak bununla Marx’n yabancılaşma kuramı arasında bağlantılar kurmaya çalışır. Brudney’e göre hem Marx hem Rawls, bireylerin iyi yaşam anlayışlarının peşinden gidebilecek imkânlara sahip olduğu koşulları sağlayan ve koruyan bir toplum tahayyül ederler (2014:455). Rawls'un iyi düzenlenmiş toplumundaki vatandaşlar da aynı Marx’ın komünistleri gibi farklı alanlarda yetkinleşme peşindedir. Rawls’un örtük yabancılaşması Marx'daki yabancılaşmanın bir boyutu olan saygıyla ilgilidir. Adaletin ilkelerini diğerleriyle paylaşmayan bireyin kendini ikinci sınıf vatandaş olarak hissetmesi durumunu ifade eder ve bununla bağlantılı olarak bireyin diğer vatandaşların kendi durumunu umursamadıklarını düşünmesiyle ilgilidir (2014:458-459). Marx'la bağlantısına gelince, Brudney, Marx’ın nesnel bir yabancılaşma olarak emekle ilişkili bir biçimde ortaya koyduğu yabancılaşmanın, Rawls'daki (örtük bir yabancılaşma kuramı olduğunu kabul etsek bile) yabancılaşmayla konusunun farklı olduğu dolayısıyla ikisinin karşılaştırılamayacağı fikrine karşı çıkar. Brudney, Marksist okumayı

19 Rawls’un, ideal kuramı için böyle bir tehlike gördüğünü söylemek zordur. Bu nedenle özsaygının toplumsal temellerini baltalayabilecek nesnel unsurlara değinmez. Bunun yerine, Rawls bu noktada biri sezgisel, diğeri evrensel iki uçlu bir sağlama stratejisine güvenir. Bunlardan sezgisel olan özsaygının zedelenmesi olarak utanç (shame), evrensel olan ise fazilettir (excellence). Rawls’a göre bu faziletler hayal gücü, güzellik, zerafet, zekâ ve erdemler gibi sadece onlara sahip olanları değil diğer insanların da doğasını gerçekleştirmesini sağlayan insani yönler, özellikler, değerlerdir. İnsanın serpilmesinin koşulu olan bu faziletler herkes için birer kaynaktır. Utanç Rawls’a göre bu faziletlere sahip olamamak ya da bunlardan faydalanamamanın sonucu olarak ortaya çıkar. Ne var ki farklı iyi yaşam anlayışlarına sahip olan bireyler sadece yaşam projelerinin gerektirdiği faziletlerin eksikliğinden (örneğin müzisyen olmayı arzu etmeyen birinin müziğe yeteneği olmamasından utanmaması gibi) utanırlar. Doğal (doğal insani özelliklerle ilgisi açısından) ya da ahlaki olarak karşımıza çıkan utançtan kaçınmak ve kendi yaşam projesini gerçekleştirmek için ihtiyaç duyduğu faziletlere sahip olmak her akılcı birey için önemlidir (2005:443-444). 
aynı Elster gibi zayıf ve güçlü yorumlar şeklinde ikiye ayırarak iyi anlayışını yabancılaşmamış emek üzerine ve bu nedenle Rawls'un toplumunun yabancılaşmış emeğe izin vereceği için hala yabancılaştırıcı olacağını savunan güçlü yorum yerine, iyi anlayışını yabancılaşmamış emek yerine tanınma üzerine kuran zayıf yoruma sarılır. Bu zayıf yorum, Brudney’e göre Rawls’un kuramiyla uyumludur (2014:465).

Brudney'den farklı olarak biz, nesnel yabancılaşma ile özsaygı arasında ortak payda aramaktan ziyade, özsaygı ile öznel yabancılaşmanın bazı ortak noktaları olabileceğini ileri sürüyoruz. Biri adalete, diğeri eşitliğe referans veren bu iki kavram, temelde politik düzenin normatif kuramlarıdır. Yabancılaşma da örneğin araçsallaşmış emek eleştirisinde ve Rawls'ta etik kıstaslara göre tasarlanmış adalette bu normativiteyi görürüz. Rawls, tamamen spekülatif düzeyde tasarladığı kuramını, ideal anlamda adil bir durumun soyut olarak tasarlanması üzerine kurmuştur. Şu an var olan koşullar, bu model çerçevesinde adaletin soyut ilkelerini gerçekleştirmediği için eleştirilir. Oysa yabancılaşmada kuramsal tasarı, temel kaynaklarını toplumsal grupların pratik deneyimlerinde bulur.

Rawls, elle dokunulur ve güncel olan bir "iyi yaşam" kavramsallaştırması yapmayı sağlayacak argümanları tam olarak vermez. Özsaygıda "iyi bir yaşam”a dair açık bir referans yoktur. Belki özsaygı üzerinden daha ileri analize başvurularak bu noktaya muhtemel bir açıklama getirilebilir, ama "iyi yaşam" hiçbir zaman Rawls'un temel sorunsalını oluşturmaz. Özsaygıyı bireylerin kendi yaşam projelerinin peşinden gitmeye arzulu olmaları, projelerini gerçekleştirmeye değer bulmaları olarak tanımlarsak, bu noktada olası bir "iyi yaşam" dili olduğunu ileri sürebiliriz.

Yabancılaşma yorumlarında özellikle 1960'larda nesnel "iyi yaşam” kuramları önemli bir yere sahipti. ${ }^{20}$ Oysa daha sonraki yıllarda yapılan eleştirilerini de dikkate alarak kullanılan anlamıyla yabancılaşma, bireyin nasıl daha iyi bir yaşama sahip olacağını anlatmaz. Daha ziyade bireylerin dünyayı sahiplenme ve kendini gerçekleştirme süreçlerini anlatır. Bizim yorumladığımız haliyle yabancılaşma, belki doğrudan "iyi yaşam" biçimine gönderme yapmaz ama tercih edilebilir yaşam formları olduğunu ifade eder. Bazı yaşam biçimlerinde, birey kendi kendini sınırlamaz ve kendisiyle olduğu kadar başkalarıyla ve dünyayla olan ilişkilerinde de kendini gerçekleştirme olanaklarından mahrum olmaz. Dolayısıyla yabancılaşma, yaşanan koşulları eleştirerek, kendisiyle ve dünyayla temas noktalarında, kişiye yabancı ve düşman olarak görünmeyen, varoluşsal anlamda nesnel olarak tercih edilebilir yaşam biçimlerini işaret eder. Bu nedenle kendini gerçekleştirme, neyin yapıldığı ile değil nasıl yapıldığıyla ilgilidir. Başka bir deyişle kendimizi etkinliklerimizde nasıl gerçekleştirdiğimizle ilgilidir (Jaeggi, 2014:174). Bu kendini gerçekleştirme durumu ise daha önce de belirttiğimiz üzere dünya aracilığıyla olan bir süreçtir ve dünya burada toplumsal ilişkileri ve tanınma ilişkilerini (relations of recognition) içerir.

Özsaygı kavramında da tanınma ilişkilerinin varlığını iddia edebiliriz. Bu tanınma ilişkileri hem kamusal tanınma hem de bireyler arası tanınmadır. Hatta özsaygıyı toplumsal tanınmada buluruz (Lazzeri, 2004:167). Tanınma, bireyin farklı yaşam projelerinin gerçekleşmeye değip 
değmeyeceğini belirleme noktasında kaçınılmazdır. Eğer kişi bu çabaya değdiğine ikna olursa onu gerçekleştirecek özsaygıya da sahip olacaktır. ${ }^{21}$ Örneğin Rawls, kuramında bireyin topluluktan izole edilmiş, atomlaştırılmış olduğu ve bunun da gerçeklerle örtüşmediği yönündeki cemaatçi eleştirilere (C. Taylor, M. Sandel, A. MacIntyre) kuramındaki sözleşmenin, herkesin kendi insani gelişimi için diğerlerinin gelişimine ihtiyaç duyduğu fikrinden hareket ettiğini belirterek yanıt verir. Rawls için her bireysel yaşam toplumun kurumlarını mümkün kılan büyük bir projenin bir parçasıdır (2005:571). Dolayısıyla, her iki kavramın da toplumsal yönü ağır basar.

Fakat özsaygı ve yabancılaşma kavramları arasında nitelikleri itibariyle temel farklılıklar vardır. Örneğin Rawls’da iyi düzenlenmiş toplum fikri, genellikle liberal kuramlarda sözleşme dışında kalması gereken bir alan olarak değerlendirilen iktisadi düzeni de kapsasa bile adil bir iktisadi ilişkiler kuramı oluşturmaz (Bidet, 1995:84). Oysa yabancılaşma kuramı doğrudan iktisadi ilişkilerin merkezindedir. Özsaygı kendini yapıcı bir eleştiriyle sınırlamıştır. Oysa yabancılaşma kuramı, farklı formlarıyla, durumları tasvir etme noktasında betimleyicidir. Bu formların nasıl yaşandığı noktasında teşhis edici ve yabancılaşmanın toplumsal faktörlerini dillendirirken eleştireldir. Yabancılaşma eleştirisi, dönüştürücü bir eleştiridir. Bu niteliklerinden ötürü de dinamik bir yapıya sahiptir.

\section{Sonuç}

Çoğulcu itirazların dile getirdiğinin aksine yabancılaşma eleştirisinin de aslında Rawls'daki özsaygı kavramıyla ilişkili kendini gerçekleştirme düşüncesindeki gibi farklı yaşam biçimlerine ve topluluk değerlerine arkasını dönmediği görülmektedir. Ancak iktisadi, siyasi ve toplumsal boyutlarıyla birlikte ele alındığında yabancılaşmanın Rawls’un özsaygı kavramının içerdiği dolayımlardan daha kapsamlı olduğu söylenebilir. ${ }^{22}$ Rawls’un kuramında özsaygının temelleri öncelikle kendini kurumlara göre hizalayan bireyin öznel durumunu yansıtır. Adaleti bir erdem olarak benimsemiş kurumlar, örneğin iktidardaki politik gücün farklı yaşam projelerini nasıl değerlendirdiğinden bağımsız olarak vatandaşlara eşitler olarak muamele eder. Özsaygının toplumsal temelleri ancak böyle bir eşit vatandaşlık düzleminde, bireylerin birbirlerine güvendikleri gibi öncelikle bu kurumların hakkaniyetli olduğuna da inandığı ve güvendiği bir ortamda mümkündür. Özsayg1 bu nedenle iyi düzenlenmiş bir toplumda temel yapının kurumlarından, yani devletin sağladığ

21 Tanınma tartışmaları, özellikle A. Honneth'in çalışmalarıyla yeni bir çerçeveye oturmuştur. Öyle ki sosyal kuramların bugünkü tartışmalarını N. Fraser, "dağıtımcı siyasetten” (politics of redistribution) "tanınma siyasetine" (politics of recegnition) bir geçiş olarak betimler. Buna göre ilk kavram özgürlüğün bir vektörü olarak düşünülen malların yeniden dağıtımı çerçevesinde tasarlanan toplumsal adaleti amaçlarken ikincisi, herkesin bireysel haysiyetinin tanınmasını amaçlayan adil bir toplumun koşullarını anlatır. Honneth bu normatif kuramında, yeniden yapılandırıcı ya da negativist yöntemle, Habermas ve Rawls'a alternatif olacak bir adalet kuramı kurmayı hedefler. Bkz. Honneth \& Fraser, 2004 ve Honneth, 2005.

22 Örneğin Marx "kaynağını Fransız Devrimi’nde bulan siyasal kurtuluşu da bir tür siyasal yabancılaşma olarak yorumlar çünkü bu kurtuluş, siyasal özgürlügü, yalnızca yurttaşlık, diğer bir deyişle, gerçek toplumsal hayattan kopuk olup bu hayata dışarıdan hükmeden bir devlete katılma biçimi altında kavrar” (Duménil, Löwy, Renault, 2011:184). 
koşullardan beklenir (Bidet, 1995:17). Bu açıdan bakıldığında Marx'daki yabancılaşmadan konumlanışı itibariyle de ayrılan eşit vatandaşlık temelli özsaygının sınırlarını görebiliriz.

Brudney'in Rawls ve Marx’’ yabancılaşma üzerinden buluşturma çabasına ilişkin olarak ayrıntılı eleştiriler getirilebilir. Ancak bu eleştirilerin bir kısmına önceki bölümde zaten değinildiği için Brudney'in atladığı bir ayrıma dikkat çekmekle yetineceğiz. Rawls'un toplumunun yabancılaşmış emeğe izin verip vermemesi hususu bir yana, Rawls için öncelikle kurumların erdemi olarak adaletin, adalet duygusunu benimsemiş makul (reasonable) iyi anlayışlarına ${ }^{23}$ sahip vatandaşların birbirlerine ve adil kurumlara güvenmesiyle mümkün olduğunu belirtmek gerekir. Bu Rawls’un kuramında devletin ağırlığını hissetmemize neden olur. İdeal kuramda vatandaşlar, bu baskıyı birbirlerine güvenerek, anlamlı etkinlikler içinde tanınacakları topluluklar kurarak kırarlar ve özsaygılarını bu sayede korumuş olurlar. Ancak Rawls’ta örtük bir nesnel yabancılaşma kuramı olduğunu düşünmemiz için inandırıcı sebepler bulmak zordur. Böyle bir örtük kuramdan söz edilebilse bile bunu kurumlar nezdinde eşit vatandaşlığa ve farklı iyi anlayışlarının uyumuna engel teşkil eden durumlarla ilişkilendirmek gerekir. Rawls'da bu "hakkaniyet olarak adalet" fikrinin önemli bir parçası olan "ideal olmayan kuram”ın konusu olarak karşımıza çıkar. Ancak burada da Rawls için önemli olan daha az elverişli koşullarda benimsenecek ilkeler olduğundan belli bir seviyede özsaygıdan ödün vermek, örneğin eşitsiz özgürlügün söz konusu olduğu durumlarda kurumların iyileşmesi Rawls’a göre gerçekçi olduğu ölçüde, ideal olmasa da savunulabilir bir durum olabilir. Bu pencereden bakıldığında özsaygı ancak bir eşitsiz özgürlük sorunu içinde ve kurumlar bağlamında ele alınabilir görünmektedir. Dolayısıyla dondurulmuş bir zaman ve toplumda belli seviyelerde kabul edilebilir bir nosyon olarak tarihsel bağlamından kopartılan özsayg 1 kavramıla tarihsel-toplumsal ve ekonomik mekanizmalar arasında bağlantı kurulması zor görünmektedir. Oysa Marx için yabancılaşma ister kurgusal bir tanrı krallı̆̆ında olsun ister bir devlet nezdinde, formel eşitlik üreten toplumsal, kurumsal mekanizmalar üzerinden de işliyor olabilir. Bu da Marksist yabancılaşma kuramına çoğulculuk sorunları çerçevesinde sıkışan özsaygı kavramının sunduğundan daha geniş bir çerçeve ve dönüştürücü bir potansiyel sağlamaktadır.

Liberaller, çoğulcu bir yaklaşımın tercihlere saygı duyması gerektiğini ve bu nedenle adaletin ilkelerinin de tercihlere duyarlı olması gerektiğini düşünürler. Ancak kapitalist toplumlarda bireylerin algılarını, değerlerini, inanışlarını ve amaçlarını, var olan çelişkilerle uyumlu yaşam projeleri geliştirmelerini sağlayacak şekilde yönlendiren mekanizmalar söz konusudur. Kymlicka’nın da kabul ettiği üzere "eğer insanlar tercihlerini gerçekçi olarak başarmayı umdukları şeye uyarlayabilirlerse çok sayıda insana önemli fırsatlar tanımayı reddeden baskııı bir toplum

23 Rawls’un akılcı olanla (rational) makul (reasonable) olan arasında yaptığı ayrım kuramında çoğulcu eleştirileri dikkate alarak yaptığı değişikliklerle daha da önemli bir hale gelmiştir. Rawls’a göre iyi düzenlenmiş bir toplumda bireyler yalnızca akılcı değil, aynı zamanda makuldürler. Bunun anlamı adil bir iş birliği sistemi içinde yer alan ve akılcı bir biçimde kendi çıkarlarını gözeten bireylerin herkesin kabul edebileceği adil ilkelerle düzenlenmiş bir iş birliği sistemini kabul etmeleridir. Bireyler, genel (ortak) irade (general will) adına değil, kendileri için makul davranırlar. Bencilce bir tutum yerine, adil iş birliği ilkelerini ihlal etmeyen bir tutumu tercih ederler. Rawls'un kuramında bu iki kavram birbirini tamamlar. Sadece makul olan bireyler adil iş birliğinden elde edecekleri kaynakları kendilerine ait amaçları olmadığı için kullanamazlar. Sadece akılcı olanlar ise bir adalet duygusundan (sense of justice) yoksundurlar ve diğerlerinin taleplerinin geçerliliğini kabul etmezler. Fakat birbirini tamamlayıcı olsalar da bu iki kavramın Rawls için birbirinden türetilemeyecek, ayrı kavramlar olduğunu vurgulamak gerekir. (Rawls, 1993:48-54). 
bile insanların tercihlerini (uyarlanmış tercihlerini) karşılamakta başarılı olabilir” (Kymlicka, 2006:21). Bu durum, çağdaş tüketim toplumlarının derin eşitsizliklere rağmen ayakta kalmasını sağlayan unsurlardan biridir. Dahms, burjuva toplumunda meşruiyetini toplumun tüm bireylerinin çıkarlarını savunduğu iddiasından alan politik düzen ile istikrarlı bir sınıf eşitsizliği gerektiren ekonomik sistem arasındaki gerilimin bir toplumsal güç olarak yabancılaşmanın kaynağını oluşturduğunu savunur (Dahms, 2005:26). Nüfuz edilemeyen derin eşitsizlikleri sürekli yeniden üreten sistemin yanında çeşitli toplumsal sorunlarla mücadele etmek üzere (ki bu da aslında eşitsizliklerin meşru olmadığının kanıtıdır) bir politik aygıtın varlığı bu gerilimi sürekli besler. ${ }^{24}$ Böyle toplumlarda "eşit vatandaşlık" anlamlı yaşam projelerinin altını oyan bir simülasyona indirgenmiştir.

Çoğulcu eleştirilerin kapitalist toplumlarda yüceltilen değerlerden ve yaşam biçimlerinden yola çıkan dar bir vizyona sahip olduğu görülmektedir. Çünkü, çoğulcu kuram farklı yaşam biçimlerini desteklediğini iddia etse de tek tipleştirici toplumsal, kurumsal ve iktisadi süreçlerin nesnel boyutlarını ortaya koyan eleştirel bir yaklaşımı dışlar. Oysa yabancılaşma, tek tip yaşam biçimine yönelttiği eleştiriler bakımından daha işlevsel bir kavramdır. Ayrıca sadece başta üretim araçlarının ve genel olarak özel mülkiyetin varlığından değil, emeğin örgütlenmesinde örneğin, öz yönetimle aşılabilecek devletçi sistemlerdeki karar alma tekelinden de kaynaklandığı düşünülürse (Barnard, 2008:11) yabancılaşma eleştirisi farklı toplumsal örgütlenme biçimlerine izin verir. Çoğulcu itirazlar, yabancılaşma kavramının çağdaş siyaset felsefesi dışına itilmesini haklı çıkarmak için yeterli değildir. Çağdaş siyaset felsefesi içinde özsaygı kavramı öznel yabancılaşmaya dair bir kapı aralasa bile genel bir yabancılaşma kuramına yer verilmesi yalnızca Marksist düşünürler için değil, adil bir toplum düşüncesi peşinde olduklarını savunan eşitlikçi liberallerin mevcut toplumsal sorunlarla bağ kurabilmesi için de önem taşımaktadır.

24 Dahms bu fikri daha da ileri götürerek hesapta bireylerin yaşam şanlarını arttırması gereken sürekli yüceltilen demokratik değerlerin gerçekleşmiyor olmasının sistemin devamlılı̆̆ını sağladığını savunur (Dahms, 2005:27). 


\section{Kaynakça}

Adorno, T. W. (1998) Critical Models, New York: Columbia University Press.

Adorno, T. W. (1998) Minima Moralia: Sakatlanmış Yaşamdan Yansımalar (Minima Moralia Reflexionen aus dem beschädigten Leben, [1951], çev. Orhan Koçak, Ahmet Doğukan), İstanbul: Metis.

Althusser, L. (2003) The Humanist Controversy and Other Writings (Eds. François Matheron, G. M. Goshgarian), London: Verso.

Althusser, L. (1996) Pour Marx, Coll. « La Découverte / Poche », Paris: La Découverte.

Arneson, R. (1987) “Meaningful Work and Market Socialism”, Ethics, 97/3: 517-545.

Barnard, F. M. (2008) Pluralism, Socialism, and Political Legitimacy: Reflections on 'Opening-up' Communism, New York: Cambridge University Press.

Bidet, J. (1995) John Rawls et la théorie de la justice, Paris: PUF.

Brudney, D. (2014) “The Young Marx and the Middle-Aged Rawls", in J. Mandle; D. A. Reidy (eds.), A Companion to Rawls, Chichester: Wiley-Blackwell.

Cohen, G. A. (1978) Karl Marx's A Theory of History: A Defence, Princeton: Princeton University Press.

Dahms, H. F. (2005) "Does Alienation have a Future? Recapturing the Core of Critical Theory", in L. Langman; D. Kalekin-Fishman (eds.), The Evolution of Alienation: Trauma, Promise, And the Millenieum, Lanham, Rowman: Littlefiels Publishers.

Elster, J. (1986) "Self-Realization in Work and Politics: The Marxist Conception of the Good Life", Social Philosophy and Policy, 3/2:97-126.

Elster, J. (1999) Making Sense of Marx [1985], Cambridge: Cambridge University Press.

Fischbach, F. (2009) Sans objet. Capitalisme, subjectivité, aliénation, Paris: Librairie Philosophique J. Vrin.

Fraser, N., Honneth, A. (2004) Redistribution or Recognition?: A Political-Philosophical Exchange, (Umverteilung oder Anerkennung [2003], tra. J. Golb, J. Ingram and C. Wilke), London: Verso.

Fromm, E. (1982) Sağlıklı Toplum, (The sane society, [1955], çev. Yurdanur Salman ve Zeynep Tanrısever), İstanbul: Payel Yay.

Geras, N. (2009) Marx ve İnsan Doğası: Bir Efsanenin Reddi (Marx and Human Nature: Refutation of a Legend [1994], çev. İsmet Akça, M. Görkem Doğan), İstanbul: Birikim Yayıncılık.

Haber, S. (2007) L’Aliénation vie sociale \& expérience de la dépossession, Paris: PUF.

Haber, S. (2009) Homme dépossédé. Une tradition critique, de Marx à Honneth, Paris: CNRS.

Honneth, A. (1996) The Struggle for Recognition: The Moral Grammar of Social Conflicts (Kampf um Anerkennung [1992] Frankfurt, tra. J. Anderson), Cambridge, Mass.: MIT.

Jaeggi, R. (2009) “Vivre sa propre vie comme une vie étrangère’: l'auto-aliénation comme obstacle à l'autonomie", dans M. Jouan et S. Laugier (éd.), Comment penser l'autonomie? Entre compétences et dépendances, Paris: PUF, p. 89-108.

Jaeggi, R. (2014) Alienation, (Entfremdung - Zur Aktualität eines sozialphilosophischen Problems [2005], tra. Frederick Neuhouser ve Alan E. Smith), New York: Columbia University Press.

Kant, E. (2012) Qu'est-ce que les Lumières? (Beantwortung der Frage: Was ist Aufklärung? [1784], tra. J. M. Muglioni), Paris: Hatier.

Kymlicka, W. (2006) Çağdaş Siyaset Felsefesine Giriş (Contemporary Political Philosophy: An Introduction'dan çev. Ebru Kılıç), İstanbul: İstanbul Bilgi Üniversitesi Yayınları.

Laurent, A. (1995) L’Individualisme méthodologique, Paris: Presses Universitaires de France.

Lazzeri, C. (2004) “Le problème de la reconnaissance dans le libéralisme de John Rawls”, Mauss, no.23:165-179.

Lukes, S. (1998) Marksizm ve Ahlâk (Marx and Morality [1988], çev. Osman Akınhay), İstanbul: Ayrıntı Yayınları. 
Mandle, J., Reidy, D. A. (eds.) (2014) A Companion to Rawls, Chichester: Wiley-Blackwell.

Marcuse, H. (1968) Tek Boyutlu İnsan, (One-Dimensional Man, [1964], çev. Seçkin Çağan), İstanbul: Haşmet Matbaasi.

Marx, K. (1979) Kapital II: Ekonomi Politiğin Eleştirisi (Capital II: A Critical Analysis of Capitalist Production [Moscow: Progress Publishers, 1974], çev. Alaattin Bilgi), Ankara: Sol Yayınları.

Marx, K. (1986) Kapital I: Kapitalist Üretimin Eleştirel Bir Tahlili (Capital I: A Critical Analysis of Capitalist Production [Lawrence and Wishart, 1971], çev. Alaattin Bilgi), Ankara: Sol Yayınları.

Marx, K. (2011) 1844 El Yazmaları: Ekonomi Politik ve Felsefe, Ankara: Sol Yayınları.

Marx, K.. F. Engels (1976), Alman İdeolojisi (Feuerbach), Seçme Yapitlar, 1. Cilt, Ankara: Sol Yayınları.

Naville, P. (1970) Le salaire socialiste, vol. I: Les rapports de production, Collection Sociologie et Travail, Paris: Éditions Anthropos.

Peffer, R.G. (2001) Marksizm, Ahlâk ve Toplumsal Adalet (Marxism, Morality and Social Justice [1990], çev. Yavuz Alogan), İstanbul: Ayrıntı Yayınları.

Petrovic, G., P. L. Kohl, (2002) "Yabancılaşma” (çev. Levent Köker), Tom Bottomore (Yayın yön.), Marksist Düşünce Sözlüğü (A Dictionary of Marxist Thought'den Türkçe’ye çev. der. Mete Tunçay), s. 621627.

Rosa, H. (2012) Aliénation et accélération vers une théorie critique de la modernité tardive (tra. Thomas Chaumont), Paris: La Découverte.

Rawls, J. (2005) A Theory of Justice [1971], Cambridge: The Belknap Press of Harvard University Press.

Rawls, J. (2008) Justice as Fairness: A Restatement [2001], Cambridge: The Belknap Press of Harvard University Press.

Rawls, J. (2008) Political Liberalism [1993], New York: Columbia University Press.

Renault, E. (2006) “Du fordisme au post-fordisme : Dépassement ou retour de l'aliénation ?”, Actuel Marx, no. 39:89-105.

Roemer, J. (ed.) (1986) Analytical Marxism, Cambridge: Cambridge University Press.

Sayers, S. (2013) Marksizm ve İnsan Doğası (Marx and Alienation: Essays on Hegelian Themes [2011], çev. Şükrü Alpagut), İstanbul: Yordam Kitap.

Teboul, R. (2004) Culture et loisir dans la société du temps libre, La Tour d’Aigues: Éditions l’Aube. 
